\title{
The Problem of Coerced Consent: When Voluntary Departure Isn't So Voluntary
}

\author{
Nicolas A. Novy* \\ "The very essence of civil liberty certainly consists in the \\ right of every individual to claim the protection of the laws, \\ whenever he receives an injury. One of the first duties of \\ government is to afford that protection."
}

INTRODUCTION

Voluntary departure and stipulated removals are intended to be useful tools for foreign nationals who do not wish to contest their citizenship. Often, this allows the individual an opportunity to be reunited with their family more expeditiously, in lieu of being detained for several months awaiting an inevitable decision of removal from an immigration judge. What the foreign national often does not realize, however, is that the same laborious process they seek to avoid is also the necessary backstop enacted by Congress to protect their constitutional rights. If a foreign national voluntarily chooses to forego a hearing and their right to present evidence, the Constitution is clearly not offended. If, on the other hand, immigration officers coerce the foreign national to forego those rights, due process concerns begin to surface. Most importantly, a foreign national attempting to seek redress after being coerced into removal now has none, as they are outside the jurisdiction of the United States and its federal courts. This means foreign nationals are merely one signature away from immediate removal, often without the ability to return and challenge the tactics used by immigration officers to secure their consent.

Part I of this Article describes an overview of the Immigration and Nationality Act (INA), the statutory framework by which expedited removals such as voluntary departure and stipulated removal exist, and the benefits of these procedures for both the foreign national and the government when executed in connection with congressional intent. ${ }^{2}$

\footnotetext{
* C 2019 Nicolas A. Novy. Associate, Dechert LLP. Former law clerk in the United States District Court, Southern District of Texas for the Honorable Rolando Olvera. J.D., 2014, Villanova University School of Law; B.A., 2011, Catholic University of America.

1. Marbury v. Madison, 5 U.S. 137, 163 (1803).

2. For an overview of the INA, see infra Part I.
} 
Parts II and III discuss potential due process concerns during removal proceedings when foreign nationals have been coerced into giving up rights they are unaware of through misinformation, language barriers, and lack of legal resources. ${ }^{3}$ Part IV explores the legal rights of foreign nationals, as well as possible legal actions at their disposal if their constitutional rights are violated. ${ }^{4}$ Part V argues that courts should not shy away from extending a federal cause of action to those who suffer constitutional violations because of coerced consent tactics, especially when the individual has no other avenue for legal redress. ${ }^{5}$ Finally, Part VI suggests that simply extending a civil cause of action is insufficient to cure the underlying problem, and courts and Congress alike should take further steps in protecting the due process rights of individuals in the removal process. ${ }^{6}$

\section{THE IMMIGRATION AND NATIONALITY ACT: AN OVERVIEW}

The INA is a comprehensive body of immigration law enacted by Congress in $1952 .^{7}$ When an individual is believed to be present in the United States unlawfully, they may be subject to formal removal proceedings under section $1229 \mathrm{a}^{8}$ Under such removal proceedings, an evidentiary hearing is conducted to determine the admissibility and

3. For examples of due process violations by immigration officials, see infra Parts II \& III.

4. For a discussion of the available avenues of recourse that the foreign national may have at their disposal if their constitutional or statutory rights are violated, see infra Part IV.

5. For a discussion advocating the extension of a Bivens cause of action to coerced consent violations, see infra Part V.

6. For a concluding discussion on the effects of coerced consent violations and a few suggested remedial measures, see infra Part VI.

7. See 8 U.S.C. $\S 1101-1537$ (2012)

8. Id. $\S 1229 \mathrm{a}(\mathrm{a})(3)$ ("Unless otherwise specified in this chapter, a proceeding under this section shall be the sole and exclusive procedure for determining whether an alien may be admitted to the United States or, if the alien has been so admitted, removed from the United States. Nothing in this section shall affect proceedings conducted pursuant to section [1228 of this title]."). However, if an individual concedes deportability or admits to an aggravated felony, expedited removal proceedings may be commenced. Id. §1228(a)(3)(A) ("Notwithstanding any other provision of law, the Attorney General shall provide for the initiation and, to the extent possible, the completion of removal proceedings, and any administrative appeals thereof, in the case of any alien convicted of an aggravated felony before the alien's release from incarceration for the underlying aggravated felony."). The alien may also be subject to expedited removal under 8 U.S.C. $\S 1225$, which permits the Department of Homeland Security (DHS) to remove an alien without formal removal proceedings if they '(1) 'are physically present in the U.S. without having been admitted or paroled,' (2) are discovered 'within 100 air miles' of the United States border, and (3) cannot establish that they have been 'physically present in the U.S.' for the fourteen days prior to the encounter with immigration authorities." United States v. Raya-Vaca, 771 F.3d 1195, 1199 (9th Cir. 2014) (quoting Designating Aliens for Expedited Removal, 69 Fed. Reg. 48877-01, 48880 (Aug. 11, 2004)). 
removability of the individual before an immigration judge. ${ }^{9}$ Under the INA, the individual subject to removal proceedings has the right to competent counsel, the right to examine the evidence against them, the right to present their own evidence, the right to appeal, and the right to post a bond to avoid detention before removal proceedings. ${ }^{10}$ After the hearing, and in the event the immigration judge determines removal is proper, the individual may still petition for asylum, cancellation of removal, and adjustment of status. ${ }^{11}$

In 1996, the Illegal Immigration Reform and Immigrant Responsibility Act (IIRIRA) amended the INA and established streamlined deportation procedures that permit the deportation of certain individuals without a hearing before an immigration judge. ${ }^{12}$ Voluntary departure and stipulated removal are just a few ways that the government diverts foreign nationals away from adjudication for the sake of efficiency. ${ }^{13}$ In either case, the government must obtain the foreign national's consent to forego formal removal proceedings - and such

9. 8 U.S.C. $\S 1229 \mathrm{a}(\mathrm{b})(1)$ (2012) ("The immigration judge shall administer oaths, receive evidence, and interrogate, examine, and cross-examine the alien and any witnesses. The immigration judge may issue subpoenas for the attendance of witnesses and presentation of evidence. The immigration judge shall have authority (under regulations prescribed by the Attorney General) to sanction by civil money penalty any action (or inaction) in contempt of the judge's proper exercise of authority under this chapter.").

10. See id. $\S 1229 \mathrm{a}(\mathrm{b})(4)$ (providing that during removal proceedings, the alien has the right to competent counsel, the right to examine evidence against them, present their own evidence on their behalf, and cross-examine witnesses presented by the government); see also id. $\S 1229 \mathrm{a}(\mathrm{c})(5)$ (requiring judges to inform aliens of their right to appeal the immigration judge's decision regarding removability); id. §1226(a)(2) (providing the right to post a bond to avoid detention prior to said hearing in the discretion of the Attorney General).

11. Id. $\S 1158$ (b) (2012) (allowing the Secretary of Homeland Security and Attorney General to grant asylum to an alien who qualifies as a refugee, i.e., an alien who has been persecuted or has a well-founded fear of future persecution in his or her former country of residence); id. § 1229b(a)(1)(3) (providing the Attorney General with discretionary authority to cancel the removal of an alien who had been a lawful permanent resident of the United States for five years, resided legally in the United States for seven consecutive years, and has not been convicted of an "aggravated felony," as defined in INA); id. $\S 1255$ (providing the Secretary of Homeland Security and the Attorney General with discretionary authority to adjust an alien's status to that of a lawful permanent resident without the alien having to obtain a visa from a consular office abroad).

12. Illegal Immigration Reform and Immigrant Responsibility Act of 1996, Pub. L. No. 104-208, 110 Stat. 3009-546 (1996); see also AM. IMMIGRATION COUNCIL, REMOVAL WithOUT RECOURSE: The Growth of Summary Deportations from the United States 1 (2014), https://www .americanimmigrationcouncil.org/research/removal-without-recourse-growth-summary-deportationsunited-states [https://perma.cc/HWY6-QWWJ] [hereinafter REMOVAL WiTHOUT RECOURSE].

13. See Jill E. Family, A Broader View of the Immigration Adjudication Problem, 23 GEO. IMMIGR. L.J. 595, 636 (2009) ("What could be more efficient than funneling certain individuals away from adjudication? Waiting times are minimal and costs are low. The effort and expense of elaborate procedures are avoided. ... These savings affect both those diverted from and those who do access the immigration adjudication system. For those diverted, the process is swift and cheap. For those inside the system, the process for them is swifter because so many millions are kept out."). 
consent must be made knowingly and voluntarily. ${ }^{14}$

Stipulated removal occurs when the foreign national explicitly waives their rights to adjudicate their deportation, including any right to a hearing and an appeal, for a final order of removal that is effective immediately. ${ }^{15}$ The stipulated removal order must be signed by the foreign national and an immigration judge. ${ }^{16}$ Under 8 C.F.R. $\S 1003.25(b)(6)$, the stipulation must include "[a] statement that the alien understands the consequences of the stipulated request and that the alien enters the request voluntarily, knowingly, and intelligently." 17 If the foreign national is not represented by an attorney, the immigration judge is required to make a separate finding that the individual's waiver is made voluntarily, knowingly, and intelligently. ${ }^{18}$ The benefit of stipulated removal to the foreign national is an accelerated removal process, without the necessity of possible confinement while awaiting a formal hearing. ${ }^{19}$

Voluntary departure is a similar form of relief that permits a foreign national to voluntarily depart the United States in lieu of formal removal proceedings or a formal removal order. ${ }^{20}$ Voluntary departure may be available before the commencement of a formal removal proceeding or after its conclusion if the foreign national is found deportable. ${ }^{21}$ The practice was originally developed by administrative officers in the absence

14. See United States v. Gomez, 757 F.3d 885, 896 (9th Cir. 2014) ("[D]ue process requires that an alien be provided an individual explanation that is competently translated 'when he sign[s] the form' . . beyond an en masse explanation"); Maria S. v. Garza, No. 1:13-CV-108, 2015 WL 4394745, at *14 (S.D. Tex. July 15, 2015) (holding that "an involuntary or coerced waiver of rights is not effective and constitutes a deprivation of procedural due process" (citing Salgado-Diaz v. Gonzales, 395 F.3d 1158, 1163 (9th Cir. 2005), as amended (Mar. 10, 2005))).

15. 8 C.F.R. $\S 1003.25(b)(2019)$

16. Id.

17. Id. $\S 1003.25(\mathrm{~b})(6)$.

18. Id. § 1003.25(b); see also Gomez, 757 F.3d at 898 (holding immigration judge erred in finding foreign national's consent was made knowingly and voluntarily by simply relying on the foreign national's signature on the consent form because said evidence by itself is insufficient).

19. Family, supra note 13, at 615-17 (explaining that the "only acknowledged benefit [of stipulated removal] to the foreign national is a speedy removal").

20. See 8 U.S.C. $\S 1229$ c (2012).

21. See id. $\$ 1229 \mathrm{c}(\mathrm{a})(1)$ ("The Attorney General may permit an alien voluntarily to depart the United States at the alien's own expense under this subsection, in lieu of being subject to proceedings under section 1229a of this title or prior to the completion of such proceedings ...."); see also Marc E. Tarlock, Voluntary Departure and the Right to Reopen Removal Proceedings on the Merits, 2007 U. CHI. LEGAL F. 613, 613 (2007) ("Once initiated, removal proceedings take place before an immigration judge .... If the alien is found removable at the conclusion of the hearing, he may request voluntary departure in lieu of formal deportation."); JENNIFER LEE KOH ET AL., DEPORTATION WITHOUT DUE PROCESS (2011), https://www.nilc .org/wp-content/uploads/2016/02/Deportation-Without-Due-Process-2011-09.pdf[https://perma.cc/6NGAAC64]. Technically speaking, "voluntary return" is when a foreign national elects to depart prior to the commencement of formal removal proceedings and "voluntary departure" is relief granted by an immigration judge during the course of removal proceedings. Courts and scholars alike, however, use the terms interchangeably. Therefore, this Article will not make it a point of significant distinction. 
of express statutory provisions and first codified in the Alien Registration Act of $1940 .^{22}$ Unlike a formal order of removal or a stipulated order of removal, however, voluntary departure does not bar future entry into the United States. ${ }^{23}$ On the other hand, it also does not require an immigration judge to make a finding that the individual's consent was made knowingly and voluntarily. ${ }^{24}$ The administrative ease of securing voluntary departure may help explain its staggering growth as one of the most popular forms of removal since $2004 .^{25}$

In either case, voluntary departure and stipulated removal allow the government and the foreign national to agree on a quid pro quo. ${ }^{26}$ From the government's perspective, a voluntary departure is less costly and more efficient when administered as intended. ${ }^{27}$ Likewise, the foreign national receives several benefits such as avoiding extended detention and

22. See Alien Registration Act of 1940, Pub. L. No. 76-670, ch. 439, 54 Stat. 670, 671-73 (repealed 1952); see also 6 CHARLES GORDON ET AL., 6 IMMIGRATION LAW \& PROCEDURE $§ 74.02$ (rev. ed. 2019) (explaining that prior to the formal enactment of the voluntary departure provisions in 1940, such relief was available from administrative immigration officers).

23. Family, supra note 13, at 615 ("From the foreign national's perspective, voluntary departure is more attractive than a removal order because it does not bar future entry into the United States. Removal orders carry bars from entering into the United States that last from five to twenty years."). But see infra note 87 and accompanying text (explaining that in certain circumstances, voluntary departure can have devastating effects when a foreign national is legally present in the United States on a temporary basis).

24. Compare 8 U.S.C. $\S 1229$ c (2012) (requiring no finding of fact by an immigration judge that the foreign national has voluntarily and knowingly surrendered their right to formal removal proceedings for voluntary departure), with supra notes 15-19 and accompanying text (requiring immigration judge to confirm foreign national's waiver is knowing and voluntary for stipulated removal orders).

25. See SARA CAmpos \& Guillermo CANTOR, Am. ImMigration CounCil, Deportations in THE DARK: LACK OF PROCESS AND INFORMATION IN THE REMOVAL OF MEXICAN MigRANTS (2017), https://americanimmigrationcouncil.org/sites/default/files/research/deportations_in_the_dark.pdf [https://perma.cc/4AGU-XQEJ].

26. Dada v. Mukasey, 554 U.S. 1, 11 (2008); see also Ngarurih v. Ashcroft, 371 F.3d 182, 194 (4th Cir. 2004) ("This statutory scheme reveals Congress' [s] intention to offer an alien a specific benefit - exemption from the ordinary bars on subsequent relief - in return for a quick departure at no cost to the government.").

27. Dada, 554 U.S. at 11 (“[T]he alien's agreement to leave voluntarily expedites the departure process and avoids the expense of deportation-including procuring necessary documents and detaining the alien pending deportation. The Government also eliminates some of the costs and burdens associated with litigation over the departure."); see also Rife v. Ashcroft, 374 F.3d 606, 614 (8th Cir. 2004) ("For the Government, voluntary departure may expedite and reduce the cost of removal."); Azarte v. Ashcroft, 394 F.3d 1278, 1284 (9th Cir. 2005) ("Voluntary departure serves the practical goals of reducing the costs associated with deporting individuals from the United States and providing a mechanism for illegal aliens to leave the country without being subject to the stigma or bars to future relief that are part of the sanction of deportation."); Ballenilla-Gonzalez v. INS, 546 F.2d 515, 521 (2d Cir. 1976) (explaining voluntary departure is to prevent the practice "of using the federal courts in a seemingly endless series of meritless or dilatory tactics designed to stall [an alien's] departure from the country as long as possible"). 
the ability to "sidestep some of the penalties attendant to deportation."28 These forms of accelerated removal, however, are only valid insofar as there is mutual assent between the parties. ${ }^{29}$ Thus, when the foreign national voluntarily and knowingly chooses to forego their rights to formal removal proceedings in lieu of a more efficient and cost-effective agreement with the government, the agreement is valid and both parties benefit. $^{30}$

\section{DuE PROCESS RightS OF Foreign NATIONALS: BEFORE AND AFTER LOPEZ-MENDOZA}

The Immigration and Naturalization Service (INS) is primarily responsible for the administration of the voluntary departure process, by and through border patrol agents and immigration officers. In 1984, the Supreme Court articulated its faith in the legitimacy of the internal regulations of the INS to protect foreign nationals from constitutional violations in INS v. Lopez-Mendoza. ${ }^{31}$ In Lopez-Mendoza, however, the Court noted that its conclusion "might change, if there developed good reason to believe that Fourth Amendment violations by INS officers were widespread." 32 In the many years following the Lopez-Mendoza decision and before September 11, the United States was revered as one of the most open, and foreign-national friendly, countries to visit, travel, and reside. ${ }^{33}$

28. See Dada, 554 U.S. at 11 (explaining benefits to immigrant who elects to voluntarily depart instead of going through removal proceedings).

29. For a discussion of voluntary departure in the context of contract law, see infra note 177 and accompanying text.

30. See David S. Rubenstein, Restoring the Quid Pro Quo of Voluntary Departure, 44 HARV. J. ON LEGIS. 1, 2 (2007) ("If the alien abides by the terms of the agreement, voluntary departure affords quid pro quo benefits to both the Government and the alien. For its part, the Government avoids the costs and burdens of forced removal and potentially those associated with protracted litigation. In exchange, the alien: (1) may depart to any destination of his choice; (2) may do so at a convenient time within the prescribed departure period; (3) avoids the stigma of forced removal; and (4) most importantly, avoids an order of removal and the attendant bars to readmission into the United States that would otherwise attach if the alien were removed by the Government."); see also Romualdo P. Eclavea, Annotation, Right of Alien Who is Under Deportation Proceedings to Depart Voluntarily from United States Under \$ 244(e) of Immigration and Nationality Act (8 U.S.C.A. \$ 1254(e)), 44 A.L.R. Fed. 574, 3 (1979) ("It has been expressly recognized that the relief of voluntary departure under 8 U.S.C.A. $\S 1254$ (e) may be an important benefit to a deportable alien, because voluntary departure avoids the stigma of deportation, enables the alien to select his own destination, and facilitates the possibility of his return to the United States.").

31. See INS v. Lopez-Mendoza, 468 U.S. 1032, 1050 (1984) (holding exclusionary rule does not apply to immigration proceedings).

32. Id.

33. EDWARd ALDEN, THE CLOSING OF THE AMERICAN BORDER: TERRORISM, IMMIGRATION AND SECURITY SINCE 9/11, at 4-5 (2008) (“On September 10, 2001, the United States was the most open, and some might have said most naïve, country in the world... Government scrutiny for the more 
Such openness had ushered in a golden age of globalization by effectively recruiting the most talented, intelligent, and creative people from all over the world. ${ }^{34}$ But in the aftermath of one of the most devastating terrorist attacks on U.S. soil, there was a desperate desire to prevent another one. ${ }^{35}$ The INS and the FBI had few leads as to suspects immediately after the attack, and what, if any, attack was coming next. ${ }^{36}$ As a result, the agencies implored a broad and aggressive immigration crackdown on all foreign nationals - knocking on doors of heavily populated Arab communities and detaining millions of foreign nationals. ${ }^{37}$ Admittedly, the agencies knew these aggressive tactics would harm innocent individuals, but viewed it as "unavoidable collateral damage that was an acceptable price if it disrupted potential terrorist activity."38 The INS and border officials alike desperately wanted to demonstrate their commitment to keeping America safe and immigration statistics were exceptionally easy to measure. ${ }^{39}$ Commentators have suggested that the Department of Homeland Security (DHS) and the U.S. government became "obsessed" with these metrics and began using them as a way of proving the government's success in keeping "bad people out." 40 As a result, the critical distinction between antiterrorism enforcement and immigration enforcement has become

than 7 million visas granted each year to foreign visitors was cursory, while another 11 million travelers from Europe and nearly 25 million visitors from Canada and Mexico crossed with virtually no scrutiny at all.”).

34. AMY CHUA, DAY OF EMPIRE xxiii (2007) ("[A]t any given historical moment, the most valuable human capital the world has to offer-whether in the form of intelligence, physical strength, skill, knowledge, creativity, networks, commercial innovation or technological invention - is never to be found in one locale or within any one ethnic or religious group. To pull away from its rivals on a global scale, a society must pull itself and motivate the world's best and brightest, regardless of ethnicity, religion, or background."); see also ALDEN, supra note 33, at 20-21 (explaining the United States' biggest commercial advantage had been its openness and the importation of talent, intelligence, and workforce from its immigrants).

35. ALDEN, supra note 33, at 5 ("[I]n the aftermath of the worst terrorist attack on U.S. soil, which had left nearly three thousand people dead and their grieving families behind, the risks [of an open immigration policy] suddenly appeared vastly to outweigh the benefits").

36. See id. at 80-87. In fact, the U.S. government knew almost nothing about millions of foreign nationals residing in the United States at the time of the attack, including the hijackers themselves. Id. at 5 .

37. Id. at $84-88$.

38. Id. at 87-88; see also Karen Gullo, Aschroft Discusses New Powers, WASH. Post (Oct. 25, 2001, 7:54 PM), http://www.washingtonpost.com/wp-srv/aponline/20011025/aponline195409_000.h tm?noredirect=on [https://perma.cc/U8TG-2NNN] (discussing former Attorney General John Ashcroft's following statement: "Let the terrorists among us be warned. If you overstay your visas even by one day, we will arrest you; if you violate a local law, we will hope that you will, and work to make sure that you are put in jail and be kept in custody as long as possible" (internal quotation marks omitted)).

39. ALDEN, supra note 33, at 292.

40. Id. 
blurred. $^{41}$

Since Lopez-Mendoza and September 11, research suggests that immigration officials have regularly disregarded the internal procedures of the INA in favor of shortcuts that violate due process. ${ }^{42}$ The Ninth Circuit has recognized that "an "evident systematic policy and practice of [F]ourth [A]mendment violations' by INS" exists. ${ }^{43}$ Commentators have suggested that constitutional violations committed by immigration officers are rarely penalized and the internal review process of DHS does little to deter their unconstitutional conduct. ${ }^{44}$ Without legitimate internal deterrence, formal allegations of misconduct are significantly underreported compared to the actual incidence of unconstitutional activity by immigration officers. ${ }^{45}$ Since Lopez-Mendoza was decided, the Justice Department's internal regulations have not been successful in preventing or deterring constitutional violations. ${ }^{46}$

41. Id. at 90 ("Over time, the original goal of identifying and arresting terrorists would become inextricably muddled with a broader crackdown on illegal immigrants.").

42. See Chris Modlish, Immigrant Rights in Jeopardy: A Denial of Constitutional Protection in De La Paz v. Coy, 57 B.C. L. REV. E. SuPP. 104, 121 (2016) ("Voluminous research exposes the fact that federal immigration officials regularly and systematically disregard internal procedures designed to protect immigrants' constitutional rights."). As this author suggested, "Scholars have found that [border patrol officers] routinely violate immigrants' Fourth and Fifth Amendment rights despite internal regulations and also systematically violate internal regulations when conducting worksite immigration raids." Id. at 121. See also Henry G. Watkins, The Fourth Amendment and the INS: An Update on Locating the Undocumented and a Discussion on Judicial Avoidance of Race-Based Investigative Targeting in Constitutional Analysis, 28 SAN DIEGO L. REV. 499, 500-01 (1991) (explaining restrictions on law-enforcement actions have decreased remarkably in recent years); Nathan Treadwell, Fugitive Operations and the Fourth Amendment: Representing Immigrants Arrested in Warrantless Home Raids, 89 N.C. L. REV. 507, 507 (2011) (explaining that ICE has made warrantless home raids in violation of the Fourth Amendment a "key component" of immigration enforcement activities, contrary to specific regulations).

43. Int'l Molders' \& Allied Workers' Local Union No. 164 v. Nelson, 799 F.2d 547, 551 (9th Cir. 1986) (quoting INS v. Delgado, 466 U.S. 210, 218 n.6 (1984)).

44. See Modlish, supra note 42, at 119.

45. See CAMPOS \& CANTOR, supra note 25 , at 19 ("Of the 1,255 complaints in which CBP reported an outcome, 95 percent of the cases resulted in 'no action' against the officer or agent accused of the misconduct."); see also Stella Burch Elias, "Good Reason to Believe”: Widespread Constitutional Violations in the Course of Immigration Enforcement and the Case for Revisiting Lopez-Mendoza, 2008 WIS. L. REV. 1109, 1146-47 (2008) (advocating that the Supreme Court's decision in Lopez-Mendoza should be revisited based on the continuous and egregious violations of immigration officials).

46. See Elias, supra note 45, at 1146 . Commentators have also noted that border patrol agents' improper training, misinformation, and the encouragement of more rigorous prosecution of entry offenses since September 11 have all been influential factors in the Justice Department's failure to discourage constitutional violations perpetuated by border patrol agents and immigration officials. See Stephanie Francis Ward, Illegal Aliens on I.C.E., ABA J. (June 1, 2008, 1:10 PM), http://www.abajournal.com/magazine/article/illegal_aliens_on_ice [https://perma.cc/3J33-PE6W] (quoting Professor Daniel Kanstroom's testimony before the House Judiciary Committee: "I don't think it's because ICE agents particularly want to separate mothers from nursing babies, but there's a culture that's developed in that agency of feeling that their primary mission is to deport people.... 
One example occurs when a foreign national is removed through the use of threats and misinformation, and coerced into foregoing their due process rights. $^{47}$ Over the past decade, the practice of diverting deportation cases from adjudication has expanded to increase efficiency and minimize costs. ${ }^{48}$ Most recently, the government has promised to increase deportation numbers and accelerate the streamlining of all deportation proceedings. ${ }^{49}$ Top-ranking immigration officials have directed their employees to use these procedures in as many situations as possible, irrespective of the legal claims that the foreign nationals might have. ${ }^{50}$ The overwhelming majority (96\%) of foreign nationals selected for stipulated removal do not have access to legal counsel. ${ }^{51}$ Without such access, the foreign national solely relies on the information provided by immigration officials concerning their most basic and fundamental

They have enormous leeway, so it makes it hard for them to feel bound by the Fourth Amendment in the way we would want them to be." (internal quotation marks omitted)); see also Elias, supra note 45 , at 1138 ("The complexities and inconsistencies of the current system of immigration enforcement-where state and local actors who were previously discouraged from enforcing immigration laws are now encouraged to do so, individual officers who once believed that they should enforce immigration laws are now told that they should not, and some police officers receive immigration training and others do not—-may help explain the increased incidence of allegations of violations of immigration respondents' constitutional rights." (internal citations omitted)); FRANCISCO CANTÚ, THE LINE BECOMES A RIVER: DisPATCHES FROM THE BORDER 19-20 (2018) (detailing a former border patrol agent's account of a PowerPoint presentation addressed to new agents in which images of drug war crimes included decapitated heads in ice chests, discarded bodies in the desert, and twelve dead bodies stacked in a pickup truck post-executions were presented, and the instructor concluded with "[t]his is what you're up against ... this is what's coming").

47. For a discussion of several examples of unconstitutional coercion during the voluntary departure process, see infra notes 101-10 and accompanying text.

48. See Stephen H. Legomsky, Forum Choices for the Review of Agency Adjudication: A Study of the Immigration Process, 71 IOWA L. REV. 1297, 1313 (1986); see also REMOVAL WITHOUT RECOURSE, supra note 12 (noting the dramatic increase of stipulated and expedited removals since 2006). For a discussion regarding the questionable effectiveness of increased summary deportations, see infra note 213 and accompanying text.

49. See Exec. Order No. 13767, 82 Fed. Reg. 8793, 8793 (Jan. 25, 2017); see also AM. IMMIGRATION COUNCIL, A PRIMER ON EXPEDITED REMOVAL (2019), https://www.american immigrationcouncil.org/research/primer-expedited-removal [https://perma.cc/F6F9-V4V7] (noting that President Trump's January 25, 2017 executive order "direct[s] the Department of Homeland Security ... to dramatically expand the use of expedited removal ...." (internal quotation marks omitted)).

50. See KoH ET AL., supra note 21, at 5 (quoting an email from a high-ranking immigration officer as follows: "Please, please, please ... encourage the agents to work harder on the stipulated orders of removal .... It is really important for the agents to push the stipulated orders of removal .... Most of the [lawful permanent residents] who get out of jail are willing to take an order just to get out of jail sooner....").

51. See id. at 8. One of the reasons why the government encouraged stipulated removals after 1997 is because "it changed its internal rules to allow the use of stipulated removal on noncitizens without counsel." Id. at 8 n.32 (citing Inspection and Expedited Removal of Aliens; Detention and Removal of Aliens; Conduct of Removal Proceedings; Asylum Procedures, 62 Fed. Reg. 10312 (Mar. $6,1997))$. 
rights. ${ }^{52}$ Government records suggest that immigration officials are giving foreign nationals poorly translated, misleading, and even false information about their cases and that, according to one officer's admission, "a small minority [of ICE agents] either don't care whether they get it right or intentionally mislead the aliens as to what their rights are." 53

In the case of stipulated removals, an immigration judge is legally required to confirm that the foreign national understands the rights they are giving up and their consent is made knowingly, voluntarily, and intelligently. ${ }^{54}$ Some immigration judges have expressed concern about the process. At least one judge "has determined that the waiver is not knowing in almost all occasions" and that the foreign national who is unrepresented is often told, "that if he wants [to] get out of jail he should sign this paper." Another judge expressed the major weakness is that the process is "handing over to ICE the duty of determining whether an alien has relief available," and that ICE has "significant leverage over a pro se detained alien." ICE have funneled stipulated removal orders away from judges who demand in-person hearings, and towards judges who will sign stipulated removal orders without question. ${ }^{57}$ Remarkably, this run-around is not even required for voluntary departure. Unlike stipulated removal, voluntary departure does not require an immigration judge to confirm the waiver was obtained voluntarily and free from coercion, regardless of the potential claims to citizenship the foreign national may have. ${ }^{58}$ In sum, the lack of government resources dedicated to ensuring the fair adjudication of each claim comparatively to the large influx of foreign

52. See id. at 9 ("Because so many noncitizens targeted for stipulated removal do not have lawyers or basic information, they have no way of knowing their legal options. As a result, their waiver ... cannot be considered to be knowing, voluntary, and intelligent, as required by the government's own internal guidelines and by due process.").

53. Id. at 10 (quoting Chief Counsel Offices Responses: Stipulated Removal Process (Feb. 10, 2006) (ICE.08-1450(13)-000222-46, 233) (internal quotation marks omitted)).

54. For an explanation of the judiciary's obligation to confirm that the foreign national's waiver is made voluntarily prior to entering an order of stipulated removal, see supra notes 15-19 and accompanying text.

55. KOH ET AL., supra note 21, at 2 (quoting e-mail from A. Greer to EOIR Officials (June 15, 2006) (EOIR-2008-5140(8)-000084-87)).

56. Id. at 12 (quoting e-mail from A. Vomacka, Immigration Judge, New York, to S. Rosen and S. Burr (May 7, 2008) (EOIR-2008-5140(5)-000314)).

57. See id. at 13-14 ("In the past decade, according to EOIR's own data, over 100,000 of the almost 160,000 stipulated removal orders entered were signed by only 20 immigration judges across the country. One immigration judge in Miami, Florida, has signed nearly 10,000 stipulated removal orders in just over three years.").

58. See supra note 24 and accompanying text (discussing that voluntary departure does not require an immigration judge determine that the foreign national's waiver of their statutory rights was done so knowingly and voluntarily). 
nationals with pending cases has resulted in unconstitutional practices. ${ }^{59}$ As the psychologist Abraham Maslow once famously wrote: "I suppose it is tempting, if the only tool you have is a hammer, to treat everything as if it were a nail." 60

\section{VOLUNTARY DEPARTURE: WHAT HAPPENS WHEN NO ONE IS WATCHING}

As a result of the resource conundrum and increased illegal immigration activity, the abuse of voluntary departure and stipulated removals has risen drastically. By coercing individuals to forego the formalities of removal, the government saves a plethora of resources while bolstering their bottom-line removal statistics at the same time. It's a winwin from the government's perspective, but even noncitizens have the absolute right to due process and the consequences of such violations can be dire. ${ }^{61}$ By taking advantage of the language barrier, ${ }^{62}$ the foreign national's lack of information and their desire to avoid perpetuated detention, ${ }^{63}$ consent to forego formal proceedings is often not obtained

59. See ALDEN, supra note 33, at 297 (explaining that a 2002 INS study concluded that in order "to halt illegal immigration through enforcement alone," the department would need: over 1000\% more investigators, special agents, immigration inspectors and deportation officers, 300\% more detention beds and border patrol agents, and 100\% more attorneys); see also CAMPOS \& CANTOR, supra note 25 and accompanying text (explaining that voluntary departure has become one of the most popular forms of removal due to its administrative ease since 2004).

60. ABRAhAm H. MASLOW, The PSYChOlOGY OF SCIENCE 15-16 (1966) ("I remember seeing an elaborate and complicated automatic washing machine for automobiles that did a beautiful job of washing them. But it could do only that, and everything else that got into its clutches was treated as if it were an automobile to be washed. I suppose it is tempting, if the only tool you have is a hammer, to treat everything as if it were a nail.").

61. For a discussion regarding the due process rights of noncitizens, see infra notes 113-17 and accompanying text. In the context of expedited removal under 8 U.S.C. $\S 1225$ :

[I]mmigration officers... serve as both prosecutor and judge-often investigating, charging, and making a decision all within the course of one day. These rapid deportation decisions often fail to take into account many critical factors, including whether the individual is eligible to apply for lawful status in the United States, whether he or she has long-standing ties here, or whether he or she has U.S.-citizen family members.

REMOVAL WITHOUT RECOURSE, supra note 12.

62. See KOH ET AL., supra note 21, at 15 ("Despite the strong likelihood that many noncitizens targeted for stipulated removal do not speak English fluently, the federal government has failed to establish clear protocols to ensure that language barriers do not plague the stipulated removal process."). As one immigration official admitted: "[I]t would be really easy to trick an illiterate nonEnglish speaker into signing a request for a stip order." Id. at 14, 16 (quoting Chief Counsel Offices Responses: Stipulated Removal Process (Feb. 10, 2006) (ICE.08-1450(13).000222-46, 236)).

63. See Jennifer Lee Koh, Removal in the Shadows of Immigration Court, 90 S. CALIF. L. REV. 181, 220-22 (2017) (explaining that immigration detention "is so coercive, widespread, and racially skewed that it causes numerous independent harms - not only to migrants, but also to communities, and to the legitimacy of the immigration law system itself" (quoting César Cuauhtémoc García Hernández, Naturalizing Immigration Imprisonment, 103 CALIF. L. REV. 1449, 1455 (2015))). 
knowingly and voluntarily. Once the foreign national finds themselves on the wrong side of the border they are no longer able to challenge the coercive and unconstitutional tactics used to obtain their consent. ${ }^{64}$ The following are just a few of many examples where the voluntary departure process has gone awry.

Mr. Ernesto Salgado-Diaz entered the United States without inspection in 1989, where he lived in San Diego with his mother and daughter, a U.S. citizen, until 1996. ${ }^{65}$ In August 1996, Salgado-Diaz filed for asylum and withholding of deportation, for which INS later scheduled a hearing for him to show cause why he should not be deported. ${ }^{66}$ Before his scheduled hearing, Salgado-Diaz was walking to the grocery store when agents stopped him and asked him for his green card, merely because he appeared Hispanic. ${ }^{67}$ Salgado-Diaz informed the agents of his pending immigration hearing, but in response, they told him his signature was necessary to look up his pending immigration proceeding. ${ }^{68}$ In fact, and unbeknownst to Salgado-Diaz, he had signed a voluntary departure form and INS immediately removed Salgado-Diaz by bus to Tecate, Mexico. ${ }^{69}$

Mr. Aladino Romero-Fereyros entered the United States pursuant to a B-2 visitor-visa in $1989 .{ }^{70}$ He married a U.S. citizen in 1997, and in 1998 applied for permanent residency. ${ }^{71}$ In 2005, Customs and Immigration Services (CIS) scheduled an interview with Romero-Fereyros to discuss his applications. ${ }^{72}$ Romero-Fereyros stated that he wanted to wait for his attorney to arrive before commencing the interview; however, CIS officers

64. For a discussion regarding the foreign national's inability to seek redress after being coerced into voluntary departure, see infra notes 164-67 and accompanying text. See also REMOVAL WITHOUT RECOURSE, supra note 12, at 4 ("ICE agents who ask detainees to sign stipulated removal orders often leave the individuals confused about their options and feeling pressured to agree to give up their right to hearings. As a result, many stipulated removals cannot be said to be voluntary, knowing, and intelligent, and the procedure raises serious due process concerns.").

65. Salgado-Diaz v. Ashcroft, 395 F.3d 1158, 1160 (9th Cir. 2005).

66. Id.

67. Id. (alleging that "he was on his way to pick up orange juice from a local store ... when, merely because he appeared to be Hispanic, the agents stopped him and asked if he had a green card").

68. Id. "Petitioner has repeatedly asserted that he did not agree to leave the country voluntarily and signed the departure form only because he thought it was needed to look up his pending case. He distinguishes his circumstances from cases in which nonresidents have accepted voluntary departure as the lesser of two evils when faced with the threat of the INS instituting deportation proceedings." $I d$. at 1163 (internal quotation marks omitted).

69. Id. at 1160. Not surprisingly, the Court held the agent's actions amounted to a constitutional violation that deprived Salgado-Diaz of his due process rights and that he was coerced into his immediate removal. See id. at 1163 ("[T]he unlawful arrest and removal denied him his day in court, substituting a peremptory deportation for a considered immigration court judgment as to whether Salgado-Diaz qualified to remain in the United States with his family.").

70. Romero-Fereyros v. U.S. Att'y Gen., 221 F. App'x 160, 161 (3d Cir. 2007).

71. Id. at $161-62$.

72. Id. at 162 . 
told him he would "lose his turn if he did not begin the interview immediately." 73 In other words, the officers told Romero-Fereyros he would need to waive his right to counsel to begin the interview. ${ }^{74}$ RomeroFereyros signed the waiver and admitted to several offenses committed in the United States. ${ }^{75}$ After the interview, authorities from ICE entered the room and demanded all of Romero-Fereyros's personal belongings, including his glasses. ${ }^{76} \mathrm{He}$ was then presented with voluntary departure forms (which he could not see) and was told to sign - thereby waiving all of his procedural rights and commencing expedited and immediate removal. ${ }^{77}$

Ms. Diocelina Lopez-Flores was living in the United States when two armed men broke into her home in Texas, tied her up, gagged her, and threatened to kill her. ${ }^{78}$ The men did the same to her children. ${ }^{79}$ As a result of Lopez-Flores's cooperation with authorities in the investigation of the two armed men, she was granted U-nonimmigrant status along with her children, which permitted her family to live and work in the United States for a period of five years. ${ }^{80}$ Within that period, her fourteen-year-old daughter ran away to Mexico, and Lopez-Flores attempted to meet her at the border to retrieve her and bring her home. ${ }^{81}$ Upon arrival, immigration officials conducted an interview and detention of Lopez-Flores and her daughter. ${ }^{82}$ Despite presenting the immigration officials with valid proof of her U-nonimmigrant status, the officials erroneously concluded that she was not lawfully within the United States and that her child could not return home. ${ }^{83}$ The immigration officials then began in systematic

73. $I d$.

74. Id.

75. Id.

76. Id.

77. Id. at 164 ("[U]pon being taken into custody by ICE and served with the Notice of Intent, he was denied access to his attorney, deprived of his eyeglasses so that he could not read the Notice and pressured into waiving his $\S 238(\mathrm{~b})(4)$ procedural rights by ICE authorities. These allegations are serious. They 'are most certainly of a type that, if established, would support a finding that DHS violated Romero-Fereyros's Due Process rights, and would lead us to overturn DHS's removal order."'). In this case, the court did not find that Romero-Fereyro succeeded in his procedural due process challenge because he failed to show how said violations led to a "substantially different outcome" as he admitted to being an aggravated felon, and therefore would have "no grounds to challenge his eventual deportation." Id. at 164-65.

78. Lopez-Flores v. Ibarra, No. 1:17-cv-00105, 2018 WL 6579180, at*1-2 (S.D. Tex. Jan. 22, 2018).

79. $I d$.

80. Id.

81. $I d$.

82. Id. at *2

83. Id.; see also infra note 87 and accompanying text (explaining that the United States 
coercion with the intent of forcing Lopez-Flores to leave the United States. ${ }^{84}$ She begged the officials not to remove her and explained she had minor children at home who would be left without a caretaker. ${ }^{85}$ The immigration officials ignored her, and said "that if she wanted to see an immigration judge, 'then she would be jailed for three to six months, after which time the judge would automatically deport her." "\$66 The officials then presented Lopez-Flores with the voluntary departure forms and told her that she "needed to sign," without translating or explaining what she was signing. ${ }^{87}$

Ms. Laura S. was a citizen of Mexico and had three children in the United States with a man named Sergio $\mathrm{H}^{88}$ Sergio was physically abusive to Laura, and as a result, Laura obtained a protective order against Sergio. ${ }^{89}$ Sergio was ordered back to Mexico, where he allegedly began working for a drug cartel. ${ }^{90}$ Sergio told Laura that if he ever saw her again he would kill her. ${ }^{91}$ A little over a year later, Laura was pulled over for a minor traffic violation and could not produce the necessary paperwork to prove her legal status. ${ }^{92}$ The law enforcement officer sent her to a Customs and Border Patrol (CBP) agent, to whom she explained that "her dangerous ex-boyfriend resided in Mexico, and that she feared for her life if she returned." 93 She pled with immigration officials and "wept and begged not to be returned to Mexico." 94 The immigration officials did not inform Laura of her right to a hearing before an immigration judge or of her right to seek asylum. ${ }^{95}$ Rather, they "rushed through the proceedings" and "forcefully demanded that she sign" the voluntary departure

Citizenship and Immigration Servises (USCIS) eventually determined that the immigration officer's initial decision to deport Lopez-Flores on the basis that she had violated her U-nonimmigrant was erroneous).

84. Lopez-Flores, 2018 WL 6579180 , at *2.

85. Id.

86. Id. This is clearly not how deportation proceedings work. As described above, Lopez-Flores would have had the right to an attorney, to present evidence of her lawful status (the same evidence that the immigration officials here willfully ignored), and the right to a full hearing. See supra notes 8-11 and accompanying text.

87. Lopez-Flores, 2018 WL 6579180, at *2-3. After her removal to Mexico, Lopez-Flores eventually succeeded in returning to the United States and applied for permanent status. USCIS "denied her application on the basis of her 'voluntary' return to Mexico. However, USCIS noted that CBP incorrectly determined that [Lopez-Flores] had violated [her] nonimmigrant status and [was] removable from the United States ...." Id. at *3 (internal citation and quotation marks omitted).

88. Maria S. v. Garza, No. 1:13-cv-108, 2015 WL 4394745, at*1 (S.D. Tex. July 15, 2015).

89. Id.

90. Id.

91. Id.

92. Id.

93. Id.

94. Id.

95. Id. 
paperwork. ${ }^{96}$ In the early morning hours of the next day, the CBP agent drove her to the international bridge and forced her return to Mexico. ${ }^{97}$ Five days later, her ex-boyfriend, Sergio, abducted and killed her. ${ }^{98}$

In some cases, officers' coercive tactics during voluntary departure have been consistent enough to necessitate the issuance of an injunction. In Orantes-Hernandez v. Meese, a class of Salvadoran citizens residing in the United States, who had been taken into custody by INS, brought a civil action challenging the policies of INS and the coercive tactics used by the agents to effectuate a voluntary departure. ${ }^{99}$ The court found that " $[t]$ he widespread acceptance of voluntary departure is due in large part to the coercive effects of the practices and procedures employed by INS and the unfamiliarity of most Salvadorans with their rights under United States immigration laws." ${ }^{100}$ According to the court, "Many class members were intimidated or coerced to accept voluntary departure even when they had unequivocally expressed a fear of returning to El Salvador." 101 As a result, the court permanently enjoined federal immigration officers from coercing Salvadoran immigrants to forego their rights under formal removal processes in lieu of voluntary departure. ${ }^{102}$

In the cases outlined above, the foreign nationals were fortunate enough to return to the United States long enough for their case to be heard with the tragic exception of Laura S., who lost her life following her involuntary removal. Many victims of coerced consent, however, are not as fortunate. In the last several decades, Mexican nationals have routinely crossed the southern border to escape the systematic violence and corruption from the pervasive influence of Mexican cartels. ${ }^{103}$ Between

96. $I d$.

97. $I d$. at $* 2$.

98. Id. ("Once she returned to Mexico, Laura S. stayed at her grandmother's house. Laura S.'s friends and relatives began emergency efforts to get her out of Mexico. After learning of Laura S.'s return to Mexico, Sergio H. soon accosted her, blocking her car and beating her brutally. Laura S. was rescued by a relative. Several days later, on June 14, 2009, Sergio H. abducted Laura S. and killed her." (internal citations and quotation marks omitted)).

99. 685 F. Supp. 1488, 1494 (C.D. Cal. 1988), aff'd sub nom. Orantes-Hernandez v. Thornburgh, 919 F.2d 549 (9th Cir. 1990).

100. Id.

101. Id.

102. Id. at $1511-14$

103. See Juan A. Solis, Land of Cartels: The Downfall of Mexico's Post-Revolutionary Authoritarian Regime (2017) (unpublished B.A. thesis, Georgetown University) (on file with author). The Institutional Revolutionary Party (PRI), formed in 1929, was Mexico's sole political party until the $1980 \mathrm{~s}$. Id. at 12 . Through their reign of political dominance, "Mexican criminal organizations had a long-standing, unofficial agreement with the PRI regime," permitting them to traffic narcotics for the benefit of the Mexican economy with minimal use of violence necessary. $I d$. at 17-18. After political unrest in the late 1980s that disturbed PRI's exclusive political control, the enforcement of 
August 2016 and April 2017, the Binational Defense and Advocacy Program surveyed over 600 Mexican national migrants aged eighteen and above within ten days of their deportation. ${ }^{104}$ The following are testimonials from the survey: A twenty-year-old male deportee explained that he "felt pressured to sign documents before leaving the United States. The agents did not explain the contents of the documents I signed and did not allow me to read them. Nor did they inform me that I had a right to communicate with the Mexican Consulate."105 A fifty-one-year-old female deportee said that she repeatedly told the agent "that I did not want to sign, that I wanted to fight my case, [and] that I wanted a list of lawyers, but he said that I had to sign - there was no other way." 106 A forty-yearold female deportee explained, "They just about put a gun to my head. They said I had gotten five years [penalty] and if I didn't sign I'd get another five." 107 Even some foreign nationals that had lawyers were not given the chance to speak with them before signing the removal documents. ${ }^{108}$ A twenty-one-year-old male deportee explained that he "had to sign three forms that were folded in half so that he could not see the contents, even though he asked that they be explained to him." ${ }^{109}$ Of the nearly 600 interviewees, $50.7 \%$ said they were not allowed to read the documents before signing them and $58.1 \%$ said that the forms were only provided in English. ${ }^{10}$ As a result, children have been separated from their parents in some cases. ${ }^{111}$ Yet these individuals have no recourse if

state power became decentralized causing the agreement between the state and the Mexican cartels to deteriorate. See id. at 18. Thereafter, increased violence persisted from multiple political parties and cartel factions struggling to gain control. Id. at 50 ("[D]rug trafficking organizations could not always depend on the state to turn a blind eye anymore, and this reality reinforced the need to use violence as an alternative."). As a result, "[1]ife in Mexico has been drastically shaped by the violence and corruption surrounding drug trafficking organizations, and tens of thousands of innocent lives have been lost as a result of the state's inability, at times unwillingness, to eradicate organized crime." Id. at 54 .

104. CAMPOS \& CANTOR, supra note 25 , at 20.

105. Id. at 4.

106. Id. at 8 .

107. Id. at 10 .

108. Id. at 11 (quoting a survey participant who stated: "I got scared because I had already asked if I could place a call to my lawyer and [the border agent] said no").

109. Id.

110. Id. at 9 .

111. Nicole Abruzzo, Voluntary Departure Post-IIRIRA: A Struggle Between Equitable Considerations Promoting Clemency Measures, and Statutory Considerations Tending Towards Oppression, 21 ST. JOHN'S J. LEGAL COMMENT. 881, 886-87 (2007) ("[R]eports indicate that tens of thousands of children were left behind in 2003 by the 887,000 aliens compelled to voluntarily depart that year."). The current administration's "zero-tolerance" policy has only exacerbated the issue. An assistant federal public defender estimated that during a two-and-a-half-week period from May-June 2018 in McAllen, Texas, just one division of Texas's Southern District, more than 400 children were separated from parents whose criminal cases were heard. Alicia A. Caldwell, Mass Hearings, Uncertain Futures for Migrants Separated From 
they are unable to return to the United States and afford a lawyer. In other words, and as many commentators have noted, "[w] hat we're seeing in court is really just the tip of the iceberg." 112

\section{A DEAD END: THE LACK OF LEGAL REDRESS AVAILABLE FOR INVOLUNTARY DEPARTURES}

Ms. Lopez-Flores and countless other foreign nationals are often presented with a difficult Hobson's choice: they are told that they may forego their constitutional right to a formal hearing in lieu of a speedy departure or remain incarcerated for an indefinite amount of timeawaiting an inevitable outcome of deportation. Even foreign nationals that have a legal right to remain are being coerced to leave the country through misinformation. The former scenario almost always strips the immigrant of the right to challenge the tactics used to obtain their consent to the "voluntary" departure and not many immigrants are willing to risk months of incarceration if an immigration officer incorrectly assures them deportation is inevitable. First, this section will explore the constitutional protections afforded to foreign nationals in the U.S. legally and illegally, and second, whether there exists some avenue of legal redress if a foreign national's procedural due process rights during removal are violated.

A long line of Supreme Court precedent holds that foreign nationals, even those in this country unlawfully, are entitled to due process protection. ${ }^{113}$ "Even one whose presence in this country is unlawful, involuntary, or transitory is entitled to that constitutional protection." 114 The "fundamentals of due process" are offended if the alien has his or her liberty stripped without "notice, hearing, and an appeal" before deportation. ${ }^{115}$ Of course, a foreign national may waive his or her constitutional protections by signing a voluntary departure consent form-

Their Children, WaLl ST. J. (June 10, 2018, 4:22 PM), https://www.wsj.com/articles/mass-hearingsuncertain-futures-for-migrants-separated-from-their-children-1528662134 [https://perma.cc/J95N-L93N]. As a result, many foreign nationals whom initially plead not guilty will change their plea to guilty for the sole reason to be reunited with their children sooner. $I d$.

112. Ward, supra note 46 ("Immigration lawyers say the searches have become both — widespread and egregious - and that it is time for the court to revisit Lopez-Mendoza.").

113. See, e.g., United States v. Verdugo-Urquidez, 494 U.S. 259 (1990); Mathews v. Diaz, 426 U.S. 67, 77 (1976) ("There are literally millions of aliens within the jurisdiction of the United States. The Fifth Amendment, as well as the Fourth Amendment, protects every one of these persons from deprivation of life, liberty, or property without due process of law.”); Shaughnessy v. United States ex rel. Mezei, 345 U.S. 206, 212 (1953) ("It is true that aliens who have once passed through our gates, even illegally, may be expelled only after proceedings conforming to ... due process of law.”).

114. Mathews, 426 U.S. at 77.

115. Zhang v. Gonzales, 432 F.3d 339, 346 (5th Cir. 2005). 
as long as their waiver is made knowingly and voluntarily. ${ }^{116}$ Thus, an immigration official's failure to adequately explain the effects and consequences of signing a voluntary departure form amounts to a due process violation. ${ }^{117}$

In 1871, Congress passed a statute that was later codified as 42 U.S.C. $\S 1983$, which entitles injured persons to sue for money damages against a state official if the state official violates their constitutional rights. ${ }^{118}$ Congress did not create an analogous statute permitting an action for money damages to be brought against individual federal officers. It was not until 1971 that the Supreme Court decided Bivens v. Six Unknown Named Agents of the Federal Bureau of Narcotics, where the Court held that it would enforce a damages remedy to compensate persons injured by federal officers who violated the prohibition against unreasonable search and seizure under the Fourth Amendment. ${ }^{119}$ In the decade that followed, the Court extended the scope of the Bivens remedy to include a Fifth Amendment equal protection claim under the Due Process Clause in Davis v. Passman, ${ }^{120}$ and an Eighth Amendment claim brought by a federal prisoner in Carlson v. Green. ${ }^{121}$ Bivens, Davis, and Carlson, however, represent the only cases where the Supreme Court recognized a damage remedy against federal officials absent statutory authority. Therefore, the Supreme Court has not created a new Bivens remedy since 1980 and a Fifth Amendment procedural due process claim has never been recognized.

The Federal Torts Claims Act (FTCA) vests federal courts with jurisdiction over certain civil actions against the United States for damages caused by the negligent or wrongful acts of government employees in circumstances where a private person would be liable to the plaintiff under state law where the act occurred. ${ }^{122}$ In other words, the liability under the

116. Nose v. U.S. Att'y Gen., 993 F.2d 75, 79 (5th Cir. 1993); see also Maria S. v. Garza, No. 1:13-cv-108, 2015 WL 4394745, at *6 (S.D. Tex. July 15, 2015) (explaining that "constitutional standards are satisfied only if [the voluntary departure] waiver was made knowingly and voluntarily").

117. See, e.g., Perez-Funez v. INS, 619 F. Supp. 656, 669-70 (C.D. Cal. 1985) (enjoining immigration officials for failing to explain the consequences of voluntary departure to minor children).

118. See 42 U.S.C. $\$ 1983$ (2012).

119. 403 U.S. 388 (1971) (holding an implied damage remedy is available to compensate persons injured by federal officers who violated the individual's constitutional rights).

120. 442 U.S. 228, 248-49 (1979) (holding that a damages remedy was appropriate under Bivens against a Congressman for gender discrimination).

121. 446 U.S. 14, 19-20 (1980) (holding petitioner's estate could recover under the Eighth Amendment via a Bivens action for the wrongful death of petitioner caused by the officer's inhumane treatment and failure to provide medical care).

122. 28 U.S.C. $§ 2674$ (2012 \& Supp. 2019) ("The United States shall be liable, respecting the provisions of this title relating to tort claims, in the same manner and to the same extent as a private individual under like circumstances...."). 
FTCA arises only when state law would impose it under like circumstances in a nonfederal context. ${ }^{123}$ The Court has observed that the statutory phrase "like circumstances" does not mean under the "same circumstances" when determining whether a private analog exists under state law. ${ }^{124}$ The seminal Supreme Court case on this issue is Indian Towing Co. v. United States, where the Court held that the plaintiff's claims against the government for their negligent operation of a lighthouse were not barred solely because there were no private lighthouses in operation at the time. ${ }^{125}$ FTCA liability does not extend, however, to "uniquely governmental" functions that "could not conceivably be[] privately performed." 126

Unlike the privatization of lighthouses, a once solely regulated governmental function, deporting an individual on the basis that he or she lacks citizenship, "could not conceivably be[] privately performed." 127 As the Second Circuit has recognized, "no private citizen is empowered to certify the loss of American nationality." "128 In other words, a private individual could not be held liable under state law for abusing a process that he or she could not conceivably invoke. ${ }^{129}$ Thus, the FTCA likely fails to provide relief to an immigrant who was coerced to leave the country under voluntary departure unless he or she also has a Fourth Amendment claim for false imprisonment. ${ }^{130}$

123. Brown v. United States, 653 F.2d 196, 201 (5th Cir. 1981); see also Johnson v. Sawyer, 47 F.3d 716, 728 (5th Cir. 1995).

124. See Indian Towing Co. v. United States, 350 U.S. 61, 64 (1955).

125. See id. at 66-67.

126. Id. at 68; see also Feres v. United States, 340 U.S. 135, 141-42 (1950) (holding servicemen injured in the armed forces due to negligence of their superiors do not have a claim under the FTCA because "no private individual has power to conscript or mobilize a private army with such authorities over persons as the Government vests in echelons of command").

127. Indian Towing Co., 350 U.S. at 68.

128. Akutowicz v. United States, 859 F.2d 1122, 1125 (2d Cir. 1988).

129. See Lopez-Flores v. Ibarra, No. 1:17-cv-00105, 2018 WL 6579180, at *4 (S.D. Tex. Mar. 12, 2018) (explaining FTCA liability does not extend to an abuse of process claim where petitioner was denied due process through removal proceedings)

130. See Liranzo v. United States, 690 F.3d 78, 94-95 (2d Cir. 2012) (explaining that in the immigration context, the proper state law analogy for an unlawful detention is "a person who, entirely in his or her private capacity, places someone under arrest for an alleged violation of the law-a so called 'citizen's arrest'"); see also Camacho v. Cannella, No. EP-12-CV-40-KC, 2012 WL 3719749 (W.D. Tex. Aug. 27, 2012) (holding FTCA liability exists for false arrest made by FBI agents). Although a few courts have found the proper analogy for an immigration detention to be a detention by state law-enforcement officers, the Supreme Court specifically instructed in Olson that "a court [must] look to the state-law liability of private entities, not to that of public entities, when assessing the Government's liability under the FTCA ...." United States v. Olson, 546 U.S. 43, 46 (2005) (emphasis added). 


\section{CURBING CONSTITUTIONAL VIOLATIONS BY IMMIGRATION OFFICIALS AND THE EXTENSION OF A BIVENS ACTION}

The creation of a Bivens action for unconstitutional coercion during the voluntary departure process would not only be a device for making the foreign national whole, but it would also curb the abuse of immigration officers' current unfettered discretion. In sum, a Bivens action would hold a federal officer accountable if they willfully disregard a foreign national's constitutional and statutory rights under the INA.

\section{A. Navigating the INA's Jurisdictional Hurdles}

Before a Bivens claim may be asserted in federal court, the court itself must have proper subject-matter jurisdiction. The INA governs all aspects of immigration law, and in many instances, strips federal courts of jurisdiction in cases where the immigration officer made a discretionary decision or where the appropriate method of review is through an administrative proceeding instead of a federal district court. ${ }^{131}$ The first jurisdictional hurdle is section 1252(a)(2)(B), which provides:

$[\mathrm{N}] \mathrm{o}$ court shall have jurisdiction to review-

(i) any judgment regarding the granting of relief under section 1182(h), 1182(i), $1229 \mathrm{~b}, 1229 \mathrm{c}$, or 1255 of this title, or

(ii) any other decision or action of the Attorney General or the Secretary of Homeland Security the authority for which is specified under this subchapter to be in the discretion of the Attorney General or the Secretary of Homeland Security, other than the granting of relief under section 1158 (a) of this title. ${ }^{132}$

Section 1229 c, listed in subsection (i) above, pertains to the decision to permit voluntary departure in lieu of formal removal proceedings, at the discretion of the Attorney General. ${ }^{133}$ The Fifth Circuit held that the term "judgment" in subsection (i) applies only to discretionary determinations

131. See Lauf v. E.G. Shinner \& Co., 303 U.S. 323, 330 (1938) ("There can be no question of the power of Congress thus to define and limit the jurisdiction of the inferior courts of the United States."); see also Rubenstein, supra note 30, at 9 ("In the immigration context, Congress has vested jurisdiction in the federal circuit courts to review final orders of removal issued by the BIA ....").

132. 8 U.S.C. $\$ 1252$ (a)(2)(B) (2012) (emphasis added).

133. See id. §1229c(a)(1) (2012) ("The Attorney General may permit an alien voluntarily to depart the United States at the alien's own expense under this subsection, in lieu of being subject to [removal proceedings before an immigration judge] ....”). 
made by the Attorney General. ${ }^{134}$ Therefore, both subsections have the effect of barring discretionary decisions made by the Attorney General from judicial review. ${ }^{135}$ In the context of voluntary departure, it is the decision by the Attorney General or their agents to offer voluntary departure in lieu of formal proceedings that is insulated from judicial review. In other words, the discretion of the Attorney General is only relevant if the foreign national "is properly subject to removal proceedings" in the first place. ${ }^{136}$ In cases where the individual's waiver of their statutory rights is being challenged, the Attorney General's decision to afford the individual the option of voluntary departure is not in dispute. Likewise, the government does not have the discretion to use coercive tactics in obtaining the individual's waiver - as such conduct would violate the Constitution and the INA. ${ }^{137}$ Section 1252(a)(2)(B) therefore does not bar judicial review of such conduct. ${ }^{138}$

Section $1252(\mathrm{~g})$ of the INA presents another jurisdictional hurdle. The

134. Mireles-Valdez v. Ashcroft, 349 F.3d 213, 216 (5th Cir. 2003) (“[W]e hold [§ $1252(\mathrm{a})(2)(\mathrm{B})$ 's] ban on review of judgment[s] regarding the granting of relief precludes review only of discretionary decisions." (internal quotation marks omitted)).

135. See 8 U.S.C. § 1252(a)(2)(B)(ii) (2012) ("[A]ny other decision or action of the Attorney General or the Secretary of Homeland Security the authority for which is specified under this subchapter to be in the discretion of the Attorney General ....").

136. Lopez-Flores v. Ibarra, No. 1:17-cv-00105, 2018 WL 6579180, at*4 (S.D. Tex. Jan. 22, 2018) (explaining that only "if an alien is properly subject to removal proceedings, the Attorney General has the discretion to forego such formal proceedings in lieu of an informal and expedited voluntary removal procedure ... as long as said waiver is accomplished knowingly and voluntarily" (citing Salgado-Diaz v. Gonzalez, 395 F.3d 1158, 1163 (9th Cir. 2005))).

137. See Berkovitz v. United States, 486 U.S. 531, 536 (1988) ("Thus, the discretionary function exception will not apply when a federal statute, regulation, or policy specifically prescribes a course of action for an employee to follow."); U.S. Fid. \& Guar. Co. v. United States, 837 F.2d 116, 120 (3d Cir. 1988) ("[C]onduct cannot be discretionary if it violates the Constitution, a statute, or an applicable regulation. Federal officials do not possess discretion to violate constitutional rights or federal statutes.").

138. In some cases, immigration officials may detain a foreign national while employing coercive tactics and claim that such detention was a discretionary decision allotted by $\S 1252$ (a)(2)(B)(ii). Such argument will likely also fail, because the Attorney General does not have the discretion to violate the Constitution or federal statutes, including the INA. Section 1357 of the INA requires the following in order for an immigration officer to justify a detention:

$[\mathrm{T}] \mathrm{o}$ arrest any alien in the United States, if he has reason to believe that the alien so arrested is in the United States in violation of any such law or regulation and is likely to escape before a warrant can be obtained for his arrest, but the alien arrested shall be taken without unnecessary delay for examination before an officer of the Service having authority to examine aliens as to their right to enter or remain in the United States.

8 U.S.C. $§ 1357(a)(2)$ (2012). In many cases, the immigration official will have a difficult time showing that the foreign national was "likely to escape before a warrant can be obtained" especially if the foreign national is claiming residency in the United States. See Lopez-Flores, No. 1:17-cv00105, 2018 WL 6579180, at *6 (S.D. Tex. Mar. 12, 2018) (holding officers had insufficient cause to detain plaintiff where plaintiff legally resided within the United States and begged the officers to allow her to return home to take care of her minor children). 
relevant portion of the statute states, "no court shall have jurisdiction to hear any cause or claim by or on behalf of any alien arising from the decision or action by the Attorney General to commence proceedings, adjudicate cases, or execute removal orders against any alien under this chapter."139 The Supreme Court has held that section 1252(g)'s jurisdictional bar "applies only to three discrete actions that the Attorney General may take: her 'decision or action' to 'commence proceedings, adjudicate cases, or execute removal orders." ${ }^{\prime 40}$ The jurisdictional bar has therefore not prevented courts from reviewing constitutional claims that generally arise in the deportation context. ${ }^{141}$ In Humphries $v$. Various Federal USINS Employees, the plaintiff brought suit claiming officers violated his constitutional rights while he was in custody awaiting the execution of his removal order. ${ }^{142}$ The Fifth Circuit held that the tenuous connection between the plaintiff's claims to the decision to execute a removal order was not sufficient to bring the plaintiff's cause of action within section 1252's jurisdictional bar. ${ }^{143}$ Many other circuits have similarly followed suit. ${ }^{144}$ The Fifth Circuit, however, has held that the decision not to commence formal removal proceedings is one that does bar federal review under section $1252(\mathrm{~g}){ }^{145}$ As explained earlier, however, it is not the immigration officer's discretionary decision to offer voluntary departure that is being challenged - rather, it is the process by which the immigration officers obtain the foreign national's consent. ${ }^{146}$ As the Southern District of Texas explained:

The Court is not asked to review whether Defendants' discretionary decision was appropriate, but whether the procedures used to gain [plaintiff's] consent complied with constitutional standards. Though factually related, the procedures used to gain [plaintiff's] consent are merely ancillary to the Defendants' discrete decision to offer her a voluntary departure, and are not encompassed within $\S 1252(\mathrm{~g})$ 's

139. 8 U.S.C. $\S 1252(\mathrm{~g})(2012)$

140. Reno v. American-Arab Anti-Discrimination Comm., 525 U.S. 471, 482 (1999) (quoting 8 U.S.C. $\S 1252(\mathrm{~g})(2012))$.

141. See Humphries v. Various Fed. USINS Emps., 164 F.3d 936, $944-45$ (5th Cir. 1999).

142. See id. at 939.

143. Id. at 946 .

144. See, e.g., Jimenez-Angeles v. Ashcroft, 291 F.3d 594, 599 (9th Cir. 2002) (holding § 1252(g) did not preclude the court "from ruling on constitutional challenges to deportation procedures"); Mustata v. U.S. Dep't of Justice, 179 F.3d 1017, 1021-22 (6th Cir. 1999) (finding plaintiff's due process challenge to deportation procedures was not barred by $\S 1252(\mathrm{~g})$ ); Selgeka v. Carroll, 184 F.3d 337, 342 (4th Cir. 1999) (same).

145. See Alvidres-Reyes v. Reno, 180 F.3d 199, 206 (5th Cir. 1999).

146. See Maria S. v. Garza, No. 1:13-CV-108, 2015 WL 4394745, at *4 (S.D. Tex. July 15, 2015) (holding plaintiff's constitutional challenge to officer's coercive consent tactics does not fall into the purview of $\S 1252(\mathrm{~g})$ 's jurisdictional bar). 
jurisdictional bar. ${ }^{147}$

Therefore, the INA does not jurisdictionally bar courts from hearing a plaintiff's Bivens claim in the context of coerced consent violations.

\section{B. The Case for a Bivens Exception}

As noted, the Supreme Court has been reluctant to expand the scope of Bivens and create a judicial remedy in the face of Congressional silence. ${ }^{148}$ A decision to create a cause of action is best left to legislators in many cases, which is why the creation of a Bivens remedy implicates separation of powers concerns. ${ }^{149}$ When determining whether to recognize a cause of action under Bivens, a court must first determine whether a plaintiff's claim presents a "new context" that differentiates the plaintiff's claim in a meaningful way from a previous Bivens decision. ${ }^{150}$ If the claim presents a "new context," a court may not extend a Bivens remedy if (1) "any alternative, existing process for protecting the interest" exists or (2) there are "special factors counselling hesitation" for creating the judicial remedy. ${ }^{151}$ The Supreme Court has most recently directed that "[w]hen deciding whether to recognize an implied cause of action, the 'determinative' question is one of statutory intent."152

\section{The Abuse of the Voluntary Departure Process: A New Context}

Generally, courts do not extend Bivens remedies on an amendment-

147. Id.; see also Lopez-Flores v. Ibarra, et al., No. 1:17-cv-00105, 2018 WL 6579180, at *8-9 (S.D. Tex. Jan. 22, 2018) (“' $[\mathrm{H}]$ ad Plaintiff's consent for voluntary departure not been fraudulently obtained, the Attorney General would then have had the discretion to commence removal proceedings or, as in Alvidres-Reyes, not to commence such proceedings-it is this decision that would have been barred from judicial review. However, Plaintiff does not challenge Defendants' decision to offer her the option to waive her rights to a formal removal proceeding, instead Plaintiff challenges Defendants' conduct in coercing her to forego her procedural rights under the INA." (internal quotation marks omitted)).

148. As the Fifth Circuit recognized, the Supreme Court "has not created a new Bivens remedy in the last thirty-five years, although "it has reversed more than a dozen appellate decisions that had created new actions for damages.” De La Paz v. Coy, 786 F.3d 367, 372 (5th Cir. 2015) (quoting Vance v. Rumsfeld, 701 F.3d 193, 198 (7th Cir. 2012) (en banc)). For a discussion of the only cases where the Supreme Court has extended a Bivens remedy, see supra notes 120-22 and accompanying text.

149. Sosa v. Alvarez-Machain, 542 U.S. 692, 727 (2004); see also Ziglar v. Abbasi, 137 S. Ct. 1843,1855 (2017) ("[W]here Congress 'intends private litigants to have a cause of action,' the 'far better course' is for Congress to confer that remedy in explicit terms." (quoting Cannon v. Univ. of Chi., 441 U.S. 677, 717 (1979))).

150. See De La Paz, 786 F.3d at 372.

151. Id. at 375 (quoting Wilkie v. Robbins, 551 U.S. 537, 550 (2007)).

152. Ziglar, 137 S. Ct. at 1855 (quoting Alexander v. Sandoval, 532 U.S. 275, 286 (2001)). 
by-amendment basis. Rather, a context-specific approach is employed. ${ }^{153}$ A court must determine whether a plaintiff's Bivens claim differs in a meaningful way from previous Bivens cases decided by the Supreme Court, and if it does, then it is a new context. ${ }^{154}$ The Supreme Court has advised that the following factors should be considered when determining whether a new context is present:

A case might differ in a meaningful way because of the rank of officers involved; the constitutional right at issue; the generality or specificity of the official action; the extent of judicial guidance as to how an officer should respond to the problem or emergency to be confronted; the statutory or other legal mandate under which the officer was operating; the risk of disruptive intrusion by the Judiciary into the functioning of other branches; or the presence of potential special factors that previous Bivens cases did not consider. ${ }^{15}$

In many challenges to the voluntary departure process, the plaintiff also asserts a Fourth Amendment claim for unlawful detention. Although Bivens was originally decided on a Fourth Amendment unlawful search and seizure issue, courts have been reluctant to recognize immigrationrelated Fourth Amendment claims unless they also allege unlawful excessive force. ${ }^{156}$ However, many constitutional violations that occur during voluntary departure do not involve the use of force, such as coerced consent offenses. ${ }^{157}$ For these foreign nationals, their Fourth Amendment claims present a new context that differs in a meaningful way from the cases that have previously extended a Bivens remedy. Likewise, a Fifth Amendment procedural due process claim would also be a "new context" requiring a full Bivens analysis, as the Supreme Court has only recognized a Fifth Amendment equal protection claim. ${ }^{158}$

\footnotetext{
153. See Corr. Servs. Corp. v. Malesko, 534 U.S. 61, 68-69 (2001).

154. See Ziglar, 137 S. Ct. at 1859.

155. Id. at 1860 .

156. Compare Martinez-Aguero v. Gonzalez, 459 F.3d 618, 625 (5th Cir. 2006) (permitting a Bivens cause of action for a detained alien who was physically abused at the U.S.-Mexico border), and Lynch v. Cannatella, 810 F.2d 1363, 1369-70 (5th Cir. 1987) (assuming the existence of a Bivens remedy for physical abuse perpetrated against immigration detainees), with De La Paz v. Coy, 786 F.3d 367, 375 (5th Cir. 2015) (holding that an immigration detention that does not include an excessive force allegation is a "new context" under Bivens).

157. For a discussion of cases where the plaintiff alleges due process violations but not an excessive force claim, see supra notes 65-98 and accompanying text.

158. Compare Davis v. Passman, 442 U.S. 228, 248-49 (1979) (extending Bivens to an equal protection claim brought by an employee against a Congressman for gender discrimination), with Schweiker v. Chilicky, 487 U.S. 412, 414, 429 (1988) (declining to extend Bivens against Social Security officials for the deprivation of allegedly entitled benefits under the statute), and FDIC v. Meyer, 510 U.S. 471, 486 (1994) (declining to extend Bivens for a wrongful termination claim against a federal agency).
} 


\section{Enforcing Congressional Intent Through Bivens}

Since creating a Bivens remedy for constitutional violations during the voluntary departure process presents a new context, a new Bivens remedy may not be recognized if "any alternative, existing process for protecting the interest amounts to a convincing reason for the Judicial Branch to refrain from providing a new and freestanding remedy in damages." ${ }^{159}$ In other words, so long as a plaintiff has an avenue for some redress, a court does not need to step in and create, or supplement, the existing remedial scheme created by Congress. ${ }^{160}$ In the context of immigration law, several circuit courts have considered the INA to be a comprehensive remedial scheme and suggested that courts should "stay its Bivens hand" when considering to supplement the statute with a judicially-created remedy. ${ }^{161}$ These opinions relied extensively on the comprehensiveness of the INA scheme and the remedies therein to redress the plaintiff's grievances. ${ }^{162}$ Generally, the INA is a sufficient remedial scheme because agency norms are "closely tailored to conform with constitutional standards." 163 However, courts have previously intruded on its domain to ensure deportation proceedings conform to constitutional standards, especially where INA's remedial scheme itself is not made available to the plaintiff due to the nature of constitutional violations alleged. ${ }^{164}$ The Second Circuit concluded that when the government took actions that impaired the plaintiff's ability to seek judicial review normally afforded under the INA,

159. Wilkie v. Robbins, 551 U.S. 537, 550 (2007).

160. See Maria S. v. Garza, No. 1:13-CV-108, 2015 WL 4394745, at*8 (S.D. Tex. July 15, 2015).

161. De La Paz, 786 F.3d at 377 (5th Cir. 2015) ("Since the INA was enacted in 1952, Congress has frequently amended it," suggesting "Congress's failure to provide an individual damages remedy 'has not been inadvertent."' (quoting Schweiker, 487 U.S. at 423); see also Mirmehdi v. United States, 689 F.3d 975, 982-83 (9th Cir. 2011) (focusing on the INA's "complexity and comprehensiveness" and declining to extend Bivens because of the "extensive remedial procedures available to and invoked" by the plaintiffs through the INA).

162. Garza, 2015 WL 4394745, at *9 (explaining that in both De La Paz and Mirmehdi, the INA was available for plaintiffs to seek redress). In $\mathrm{De} L a \mathrm{Paz}$, the plaintiffs alleged they were stopped and searched in violation of their Fourth Amendment rights. 786 F.3d at 370-71. The Fifth Circuit reasoned that once detained, the plaintiffs had the remedial scheme of the INA at their disposal, which included, inter alia, the right to challenge removal at a formal removal proceeding and the right to appeal. See id. at 375-76. Likewise, in Mirmehdi, the plaintiff alleged a wrongful detention claim and the Ninth Circuit refused to extend Bivens because the plaintiff had the ability to challenge the officer's conduct through the INA's remedial scheme. See Mirmehdi, 689 F.3d at 982-83 (focusing on the alternative remedies made available to plaintiff through the INA). In the realm of coerced consent cases, however, the plaintiff does not have access to the INA's protections once the constitutional violation occurs, as they are often removed from the country immediately thereafter. See infra notes 163-65 and accompanying text.

163. De La Paz, 786 F.3d at 378.

164. See, e.g., Orantes-Hernandez v. Meese, 685 F. Supp. 1488, 1513-14 (C.D. Cal. 1988), aff'd sub nom. Orantes-Hernandez v. Thornburgh, 919 F.2d 549 (9th Cir. 1990) (enjoining federal immigration agents from using coercive tactics in immigration proceedings); Perez-Funez v. INS, 619 F. Supp. 656, 669-70 (C.D. Cal. 1985) (same). 
"any reliance on the INA as an alternative remedial scheme presents difficulties."165 Therefore, the INA is a comprehensive and sufficient remedial scheme to the extent a plaintiff has access to it. ${ }^{166}$

In addition, courts are also required to "make the kind of remedial determination that is appropriate for a common-law tribunal, paying particular heed, however, to any special factors counselling hesitation before authorizing a new kind of federal litigation."167 Courts have recognized that the special factors analysis is a remarkably low bar and that "[h]estitation is a pause, not a full stop, or an abstention." 168 The inquiry must concentrate on "whether the Judiciary is well suited, absent congressional action or instruction, to consider and weigh the costs and benefits of allowing a damages action to proceed." 169 In other words, the analysis comes down to "who should decide whether such a remedy should be provided." 170 In the context of immigration cases, courts have found the following factors counsel hesitation for extending a Bivens remedy: fear that the immigration officer may "readily shirk his duty", ${ }^{171}$ the imposition of significant costs due to a "tidal wave of litigation"; ${ }^{172}$ the

165. Arar v. Ashcroft, 585 F.3d 559, 573 (2d Cir. 2009).

166. Lopez-Flores v. Ibarra, No. 1:17-cv-00105, 2018 WL 6579180, at*11 (S.D. Tex. Jan. 22, 2018) (explaining "the INA is a comprehensive remedial scheme sufficient for protecting a plaintiff's rights to the extent a plaintiff is able to access the remedies within said scheme"). The conclusion is consistent with recent Supreme Court precedent, which reiterates that the three cases decided by the Court that justified a Bivens remedy were cases where the plaintiff had no other avenue for redress. See Wilkie v. Robbins, 551 U.S. 537, 555 (2007) ("Davis had no other remedy, Bivens himself was not thought to have an effective one, and in Carlson the plaintiff had none against Government officials.”). If a plaintiff is unable to access the remedial scheme enacted by Congress, they logically fall into the same category as Bivens, Davis, and Carlson, which all justified the creation of a judicial remedy as they were "damages or nothing" cases. Bivens v. Six Unknown Named Agents of the Fed. Bureau of Narcotics, 403 U.S. 388, 410 (1971). Subsequent to a coerced consent departure, the foreign national no longer has access to the INA's remedial scheme or the U.S. courts to seek redress, and therefore coerced consent cases present a distinctly different scenario than most Fourth and Fifth Amendment immigration-related Bivens claims.

167. Wilkie, 551 U.S. at 550 (citing Bush v. Lucas, 462 U.S. 367, 378 (1983)).

168. Arar, 585 F.3d at 574; see also Ashcroft v. Iqbal, 556 U.S. 662, 675 (2009) (explaining that extending a Bivens remedy is now a "disfavored" judicial activity).

169. Ziglar v. Abbasi, 137 S. Ct. 1843, 1858 (2017) ("[T]he decision to recognize a damages remedy requires an assessment of its impact on governmental operations systemwide. Those matters include the burdens on Government employees who are sued personally, as well as the projected costs and consequences to the Government itself when the tort and monetary liability mechanisms of the legal system are used to bring about the proper formulation and implementation of public policies.").

170. Bush v. Lucas, 462 U.S. 367, 380 (1983) (emphasis added); see also Ziglar, 137 S. Ct. at 1855-56 (explaining that the "determinative question is one of statutory intent" (internal citations omitted)).

171. De La Paz v. Coy, 786 F.3d 367, 379 (5th Cir. 2015).

172. Id. at 379-80 ("There are over 11 million illegal aliens in the United States" and it is an "easy exercise for aliens, even without an attorney, to file suit alleging, as in these cases, that there was no reasonable suspicion for their stops, arrests, or detentions"). 
suppression of legitimate evidence obtained during mass arrests; ${ }^{173}$ the possible disclosure of sensitive "foreign-policy objectives"; ${ }^{174}$ and finally, often "the aliens' ultimate remedies lie in pursuing termination of removal proceedings through the INA's many available avenues." 175

In most immigration cases, these concerns counsel some degree of hesitation when determining whether to recognize a judicially created remedy. In a coerced consent case, however, these concerns begin to lose force and counsel in favor of acknowledging a judicially-created remedy - not against it. A foreign national facing the choice of voluntary departure indeed does not want the immigration officer to "shirk his duties," but rather, comply with them. The creation of a Bivens remedy for officers who coerce individuals into voluntary departure conversely encourages officers to inform individuals of their rights to formal proceedings, consistent with their statutory obligations under the INA. At the very least, the officer would be sure that the individual could read and understand the documents they were signing, and understood the constitutional and statutory rights they were forgoing. ${ }^{176}$ It would be quite an anomaly in the execution of any other contract if the contract drafter refused to provide a translated copy of the agreement to the recipient in a language they could understand, the recipient was coerced to sign it, and the contract drafter then claimed that misrepresentation and duress were not valid defenses. ${ }^{177}$

173. INS v. Lopez-Mendoza, 468 U.S. 1032, 1049 (1984).

174. Mirmehdi v. United States, 689 F.3d 975, 983 (9th Cir. 2012) (internal citations and quotation marks omitted) (declining to extend Bivens in the immigration context given "the unique foreign policy considerations implicated in the immigration context").

175. De La Paz, 786 F.3d at 379.

176. See Perez-Funez v. INS, 619 F. Supp. 656, 669-70 (C.D. Cal. 1985) (enjoining immigration officials from failing to explain the consequences of voluntary departure to minor children). In a factually distinct but analogous scenario, an immigrant who challenges a deportation order under 8 U.S.C. $§ 1326(d)$ must show "(1) exhaustion of any available administrative remedies; (2) improper deprivation of judicial review in the underlying removal proceedings; and (3) prejudice." United States v. Lopez-Menera, 542 F. Supp. 2d 1025, 1027 (N.D. Cal. 2008) (citing United States v. OrtizLopez, 385 F.3d 1202, 1203-04 (9th Cir. 2004)). In Lopez-Menera the immigration judge failed to inform the defendant of his eligibility for voluntary departure, and such failure to inform violated defendant's due process rights. See id. at 1030. Similarly, the failure of border patrol agents to inform an individual of their procedural due process rights under the INA, or worse, misinform them, also abridges the constitutional rights of the immigrant. See Maria S. v. Garza, No. 1:13-CV-108, 2015 WL 4394745 , at $* 6$ (S.D. Tex. July 15,2015 ) (discussing voluntary departure waiver must be accomplished knowingly and voluntarily to comply with due process).

177. In the context of contract law, misrepresentation and duress are sufficient defenses to void an agreement. See ReStATEMENT (SECOND) OF CONTRACTS $§ 162 \mathrm{cmt}$. a (AM. LAW InST. 1981) (explaining that fraudulent misrepresentation occurs when the misrepresentation is "consciously false but must also be intended to mislead another"). See also Warnaco, Inc. v. Farkas, 872 F.2d 539, 546 (2d Cir. 1989) (citing Austin Instrument, Inc. v. Loral Corp, 29 N.Y.2d 124 (1971) (explaining a defense of duress must be based on proof that the party was subjected to a "wrongful threat precluding 
Likewise, the concerns of "crowded circumstances" and sensitivity to the disclosure of specific "foreign policy" have no place in the context of a coerced removal. If anything, the circumstances are far from confused and crowded as the standard voluntary departure consent forms are read and signed in the controlled environment of an interrogation room. ${ }^{178}$ Nor is it clear how there is any risk that sensitive foreign policy could be disclosed in the event the foreign national was encouraged to pursue their constitutional and statutory rights or if they were able to bring an action in federal court to vindicate those rights. ${ }^{179}$ To the contrary, the Supreme Court has recently written to emphasize the "strong national interest Congress has in protecting aliens from mistreatment." 180 As the Fifth Circuit recognized, "[t]here are ... no identifiable national interests that justify the wanton infliction of pain," 181 just as there appears to be no national interest in justifying the fraudulent obtainment of an individual's consent to removal.

From a cost perspective, the decision to recognize a damage remedy requires a court to weigh the benefits and financial burdens of imposing liability on individual officers - a decision often best left to Congress. ${ }^{182}$ The Fifth Circuit has expressed fear that extending Bivens into the immigration context would create a "tidal wave" of litigation, relying on the fact that there are eleven million undocumented immigrants in the

the exercise of free will")). In United States $v$. Ramos, the court concluded that a waiver of the right to appeal is not intelligent if it is not received in the defendant's language when he signs the form. 623 F.3d 672, 677-80 (9th Cir. 2010). For a discussion of how removal forms are often improperly translated, see supra note 53 and accompanying text.

178. See supra notes 66-98 and accompanying text (describing factual scenarios of cases where the immigration officer's detention and acts of coercion were accomplished in a controlled environment).

179. Cf. Mirmehdi v. United States, 689 F.3d 975, 982-83 (9th Cir. 2012) ("As the Supreme Court has noted, concerns that always mitigate against 'subjecting the prosecutor's motives and decisionmaking to outside inquiry' have particular force in the immigration context. Rather than mere 'disclosure of normal domestic law-enforcement priorities and techniques' such cases often involve 'the disclosure of foreign-policy objectives and (as in this case) foreign-intelligence products.", (quoting Reno v. American-Arab Anti-Discrimination Comm., 525 U.S. 471, 490-91 (1999))). In the case of coercion in the voluntary departure context, however, the "prosecutor's motives and decisionmaking" never come into play because the individual is coerced to leave the country prior to the initiation of formal proceedings against her. Id. at 983. See Lopez-Flores v. Ibarra, et al., No. 1:17-cv-00105, 2018 WL 6579180, at *4 (S.D. Tex. Jan. 22, 2018) (explaining the Attorney General's discretionary decision to offer voluntary departure is only applicable if formal removal proceedings are first legitimately commenced).

180. Hernandez v. United States, 757 F.3d 249, 276 (5th Cir. 2014) (citing Arizona v. United States, 567 U.S. 387, 395 (2012)), vacated in part and reinstated in part on reh'g en banc, 785 F.3d 117 (5th Cir. 2015).

181. Martinez-Aguero v. Gonzalez, 459 F.3d 618, 623 (5th Cir. 2006).

182. See Ziglar v. Abbasi, 137 S. Ct. 1843, 1858 (2017) ("It is not necessarily a judicial function to establish whole categories of cases in which federal officers must defend against personal liability claims in the complex sphere of litigation ...."). 
United States and Border Patrol agents accounted for 420,789 apprehensions in 2013 alone. ${ }^{183}$ The Fifth Circuit feared that it would be an "easy exercise for aliens, even without an attorney, to file suit alleging ... that there was no reasonable suspicion for their stops, arrests, or detentions." 184 This assumes, however, that the individual remains in the United States long enough to bring frivolous claims. In the context of coerced removal, the foreign national is often immediately deported after her consent is obtained. A "tidal wave" of litigation would not follow in coerced consent cases simply because most foreign nationals removed from the United States are unable to return. ${ }^{185}$

Finally, in many Bivens cases involving immigration arrests, courts have held that the immigration context counsels hesitation because the plaintiff's "ultimate remedies lie in pursuing termination of removal proceedings through the INA's many available avenues."186 Thus, creating a damage remedy in light of congressional silence counsels hesitation simply due to the existence of the INA's comprehensive remedial structure. While that may be true for standard immigration arrests and detentions, it also assumes the individual will have the ability to access the INA's protections, including the ability to seek termination of removal proceedings, a hearing in front of an immigration judge, and the right to counsel. It is quite different, however, when as a result of the constitutional violation, the individual is denied access to the INA's protections altogether. ${ }^{187}$ The challenge the plaintiff is bringing in coerced consent cases is drastically different - it is the challenge to the legitimacy of their consent which, as a result, waives all of their substantive and procedural rights under the INA and the Constitution. Without the ability to challenge the legitimacy of such consent there may be no limit to what immigration officers may do, or say, to coerce a foreign national to leave the country through the "voluntary" departure process. As the Supreme Court most recently reiterated in Ziglar, the " determinative' question" in determining the validity of a Bivens remedy "is one of statutory intent." 188 The INA is a comprehensive remedial scheme with a plethora of

\footnotetext{
183. De La Paz v. Coy, 786 F.3d 367, 379-80 (5th Cir. 2015).

184. Id. at 380 .

185. For a discussion regarding the testimonials of many foreign nationals who were deported but have no recourse to have their coerced consent violations heard because of their inability to return to the United States, see supra notes 103-12 and accompanying text.

186. De La Paz, 786 F.3d at 379.

187. See id. at 378.

188. Ziglar v. Abbasi, 137 S. Ct. 1843, 1855-56 (2017) (quoting Alexander v. Sandoval, 532 U.S. $275,286(2001))$.
} 
protections for individuals who have access to it. ${ }^{189}$ However, where an individual is deprived access to the scheme itself, it becomes the responsibility of the judiciary to not only enforce the Constitution but to enforce the statutory provisions promulgated by Congress. ${ }^{190}$ By creating a Bivens remedy in coerced consent cases, a court effectively accomplishes both.

\section{CONCLUSION}

The creation of a Bivens remedy alone will not eradicate due process violations during removal and deportation. ${ }^{191}$ Currently, few foreign nationals will be given the opportunity to present their case in a federal court, but more importantly, a Bivens remedy does not address the underlying causes that perpetuate the problem: the foreign national's lack of access to legal information and the immigration officers' incentive to remove individuals efficiently as possible in the interest of national

189. For a discussion of the protections afforded to foreign nationals under the INA, see supra notes $8-11$ and accompanying text.

190. Lopez-Flores v. Ibarra, No. 1:17-cv-00105, 2018 WL 6579180, at*11 (S.D. Tex. Jan. 22, 2018) (" $[\mathrm{N}] \mathrm{o}$ remedial scheme can be comprehensive enough to protect an individual's rights when a plaintiff is denied access to the remedial scheme itself."); see also Maria S. v. Garza, No. 1:13-CV108, 2015 WL 4394745, at*9 (S.D. Tex. July 15, 2015) ("It is illogical for Defendants to deny an individual access to a remedial scheme, then claim protection from suit based on the presence of that remedial scheme."). Judge Hanen reasoned that it is "well-established in his circuit that deportation proceedings must conform to the requirements of due process so that the defendants were given "fair warning' that their conduct, if as alleged by the plaintiffs, was not objectively reasonable." Gerald Seipp, Federal Case Summaries, 92 No. 29 INTERPRETER RELEASES 1421 (Thompson Reuters, Toronto, Can.), Aug. 3, 2015, at 1427. See also Garza, 2015 WL 4394745, at *11 ("'If a Bivens remedy is not available wherever a non-citizen has the ability to seek review of an immigration decision, there is little to deter immigration officials from presenting false evidence or testimony during immigration proceedings or from otherwise compromising the integrity of such proceedings .... Thus it is often necessary for courts to exercise their judicial power in this area to ensure compliance with constitutional standards and to protect the rights of aliens in this country." (quoting Lanuza v. Love, No. C14-1641 MJP, 2015 WL 1282132 (W.D. Wash. Mar. 20, 2015), aff'd in part, vacated in part, remanded, 899 F.3d 1019 (9th Cir. 2018))).

191. Although valiant efforts have recently been made by advocacy groups, the fight is far from over. In 2014, the ACLU obtained a favorable settlement addressing the problem of coerced consent to voluntary departure in Southern California. See Lopez-Venegas v. Johnson, No. LA CV13-03972 JAK (PLAx), 2014 WL 12772087 (C.D. Cal. Aug. 28, 2014). Pursuant to the agreement, immigration officials in Southern California were required to provide detailed information regarding the consequences of forgoing a formal hearing in front of an immigration judge, permitted non-citizens to use a working phone and provide them with legal information and legal contacts, ceased pressuring individuals to accept voluntary return as the only option, and allowed ACLU attorneys to monitor compliance for three years. The agreement, however, is limited in geography to Southern California, and further, the three-year period permitting attorneys to monitor compliance has now lapsed. See ACLU Obtains Settlement Agreement Addressing Alleged Abuse of Voluntary Return Process in Southern California, 91 No. 34 InTERPRETER RELEASES (Thompson Reuters, Toronto, Can.), Sept. 8, 2014, at 1597 . 
security. ${ }^{192}$ The government's reliance on removal statistics as proof of national security is both over-inclusive and under-inclusive. The original goal of narrowly identifying and arresting terrorists has been inextricably muddled with a broader and comprehensive crackdown on all foreign nationals. ${ }^{193}$ What once looked like a reasonable response to a devastating terrorist attack has now become a cure that's worse than the disease.

A simple example may prove instructive. On November 14, 2007, a fire broke out in the Anchorage Inn, a historical landmark in New York near the U.S.-Canada border. ${ }^{194}$ Under an agreement between the United States and Canada that had been in place since the 1950s, either country was able to call on firefighters from across the border for assistance if necessary. ${ }^{195}$ But that night, the Canadian fire truck that arrived at the border with their lights flashing was stopped and asked to produce identification. ${ }^{196}$ One of the firefighters whose identification was checked had a criminal record, raising doubts about whether he should be allowed to cross the border to fight the fire at the Anchorage Inn. ${ }^{197}$ After eight minutes of interrogation, the border patrol agent permitted the firetruck to cross, but by the time the truck arrived, the historic Anchorage Inn had already burned to the ground. ${ }^{198}$ As Edward Alden in The Closing of the American Border explains:

The officials at the border saw their responsibility through a single lens, which has been reinforced repeatedly since $9 / 11$ - keeping bad people out of the United States. But that should not have been the only measure; it was equally important that they be able to let good people into the country quickly and efficiently. By failing to do so, it was the United States - not Canada, not the firefighters themselves - that paid the highest price. ${ }^{199}$

In removal proceedings, the foreign national often lacks even the most

192. For a discussion of the foreign national's lack of access to legal information, see supra note 51 and accompanying text. For a discussion of the government's incentive to remove as many foreign nationals as possible with the resources available, see supra notes 31-60 and accompanying text.

193. See ALDEN, supra note 33, at 90.

194. Jeanne Meserve \& Mike M. Ahlers, Canadian Firetruck Responding to U.S. Call Held up at Border, CNN (Nov. 14, 2007), http://www.cnn.com/2007/US/11/14/border.firetruck/ [https://perma.c c/T6QZ-NZNR].

195. ALDEN, supra note 33, at 288.

196. Id.

197. Id.

198. Id.

199. Id. at 290 ("The ability of the United States to attract the most ambitious immigrants from around the world has been a central reason for its economic and diplomatic success, yet we are now making it harder for them to come here at a time when other countries-many of them no less vulnerable than the United States to terrorist attacks—are making it easier."). 
basic understanding of the proceedings and is unrepresented by counsel in almost all cases. ${ }^{200}$ This is the paradigm that permits coerced consent cases to perpetuate. ${ }^{201}$ The addition of more immigration attorneys and more immigration judges to formally adjudicate the foreign national's right to remain is one possible solution that has been fiercely advocated but would come at great expense. ${ }^{202}$ A lack of resources, crowded immigration courts, and overwhelmed immigration judges are well documented. ${ }^{203} \mathrm{~A}$ compromise, however, might be to require immigration officials to advise foreign nationals of their rights more specifically as police officers must now do at the time of an arrest pursuant to Miranda v. Arizona. ${ }^{204}$ In the not-so-distant past, officers could extort criminal confessions by any means necessary. ${ }^{205}$ Just before Miranda was decided, the police in New York "brutally beat, kicked and placed lighted cigarette butts on the back of a potential witness under interrogation for the purpose of securing a statement incriminating a third party." ${ }^{206}$ In response, the Miranda Court held as follows:

200. See supra note 51 and accompanying text (explaining nearly $96 \%$ of foreign nationals are unrepresented in removal proceedings).

201. The U.S. government "spent $\$ 5.9$ billion to detain immigrants in the fiscal year 2009 , [and] it spent less than $0.07 \%$ of that amount to provide detainees with legal rights information." Isolated in Detention: New NIJC Report Details Widespread Lack of Legal Counsel for Detained Immigrants, NAT'L IMMIGRANT JUSTICE CTR. (Sept. 14, 2010), https://www.immigrantjustice.org/press-releases/is olated-detention-new-nijc-report-details-widespread-lack-legal-counsel-detained [https://perma.cc/9 VFT-D48X].

202. KOH ET AL., supra note 21, at 18 (recommending that immigration judges should hold a hearing to determine the validity of the foreign national's consent to each stipulated removal order, and that "[t]hese stipulated removal hearings would be akin to plea colloquies in criminal proceedings, where judges must advise defendants of certain rights and consequences of accepting a plea in order for a guilty plea to be valid").

203. See Nolan Rappaport, Trump's Fast-Tracked Deportations May Be Only Solution to Backlog, HILL (Oct. 19, 2017), http://thehill.com/opinion/immigration/356211-trumps-fast-tracked-deportation s-may-be-only-practical-solution-to [https://perma.cc/M9SY-54P6] ("As of the end of August 2017, the immigrant court's backlog was 632,261 cases, and the immigration court has only 330 immigration judges. The backlog is getting larger every year because the judges are not even able to keep up with the new cases they receive each year."). "At a panel discussion on the immigration court backlog, Immigration Judge Larry Burman said, 'I cannot give you a merits hearing on my docket unless I take another case off. My docket is full through 2020, and I was instructed by my assistant chief immigration judge not to set any cases past 2020." Id. See also Koh, supra note 63 ("Commentators with good reason frequently deploy the word 'crisis' to describe the state of the immigration courts. The deficiencies of the immigration court system are well-documented and arguably cast doubt on the legitimacy and integrity of mainstream immigration adjudication.").

204. 384 U.S. 436 (1966).

205. Miranda v. Arizona, 384 U.S. 436, 446 (1966) (citing Brown v. Mississippi, 297 U.S. 278 (1936); Chambers v. Florida, 309 U.S. 227 (1940); Canty v. Alabama, 309 U.S. 629 (1940); White v. Texas, 310 U.S. 530 (1940); Vernon v. Alabama, 313 U.S. 547, 61 (1941); Ward v. Texas, 316 U.S. 547 (1942); Ashcraft v. Tennessee, 322 U.S. 143 (1944); Malinski v. New York, 324 U.S. 401 (1945); Leyra v. Denno, 347 U.S. 556 (1954)).

206. Miranda, 384 U.S. at 446 (citing People v. Portelli, 205 N.E.2d 857 (N.Y. 1965)). 
We have concluded that without proper safeguards the process of incustody interrogation of persons suspected or accused of crime contains inherently compelling pressures which work to undermine the individual's will to resist and to compel him to speak where he would not otherwise do so freely. In order to combat these pressures and to permit a full opportunity to exercise the privilege against selfincrimination, the accused must be adequately and effectively apprised of his rights and the exercise of those rights must be fully honored. ${ }^{207}$

The Court went on to "encourage Congress and the States to continue their laudable search for increasingly effective ways of protecting the rights of the individual while promoting efficient enforcement of our criminal laws." 208

If Congress does not amend the INA to ensure that the foreign national's constitutional and statutory rights are safe from the same type of unconstitutional coercive tactics that were present pre-Miranda, courts should not shy from enforcing a similar requirement in the removal process. Requiring border patrol agents to translate all documents, advise the foreign national of their rights to present evidence at a hearing, their right to seek asylum, and their right to post a bond in certain circumstances does not offend the purpose of expedited proceedings - it merely informs the foreign national of the rights they are sacrificing. The protection of due process and access to legal information may be the most important in removal proceedings, as the foreign national is not only forgoing rights he or she is unaware of but is one signature away from being forced out of the country, with little or no possibility of recourse thereafter. The finality of a coerced consent due process violation is a primary reason why the problem perpetuates. For that reason, and to guarantee the preservation of unappealable due process rights, Congress may conclude that every waiver of formal removal proceedings should be heard, at least briefly, by an immigration judge to confirm that the individual's waiver was made knowingly, voluntarily, and free from coercion. Despite the backlog that currently exists in immigration courts, Justice Harlan, in his Bivens concurrence, explained the resource conundrum as follows:

Judicial resources, I am well aware, are increasingly scarce these days. Nonetheless, when we automatically close the courthouse door solely on this basis, we implicitly express a value judgment on the comparative importance of classes of legally protected interests. And current limitations upon the effective functioning of the courts arising from budgetary inadequacies should not be permitted to stand in the way of

207. Id. at 467 .

208. Id. 
the recognition of otherwise sound constitutional principles. ${ }^{209}$

The problem of coerced consent in the voluntary departure process is unique. In the case of stipulated removals, federal regulations dictate that immigration judges are required to make a factual finding that the foreign national is forgoing their right to a hearing knowingly and voluntarily. ${ }^{210}$ If the foreign national is subject to expedited removal, federal regulations dictate that immigration officials must notify the individual of their right to seek asylum ${ }^{211}$ and make an entire record of the proceedings. ${ }^{212}$ No such protections exist in the realm of voluntary departure-leaving the foreign national one signature away from unappealable deportation. Due to a lack of resources and influx of illegal immigration, the increase of summary deportations not only increases the likelihood of constitutional violations but may begin to reverse the deterrent effect that removals have on future illegal reentry offenses, especially when removals are not conducted legitimately. ${ }^{213}$

209. Bivens v. Six Unknown Named Agents of the Fed. Bureau of Narcotics, 403 U.S. 388, 411 (1971) (Harlan, J., concurring).

210. 8 C.F.R. $\S 1003.25$ (b) (2019) ("If the alien is unrepresented, the Immigration Judge must determine that the alien's waiver is voluntary, knowing, and intelligent.").

211. Id. § 235.3(b)(4) ("If an alien subject to the expedited removal provisions indicates an intention to apply for asylum, or expresses a fear of persecution or torture, or a fear of return to his or her country, the inspecting officer shall not proceed further with removal of the alien until the alien has been referred for an interview by an asylum officer in accordance with 8 CFR [\$] 208.30. The examining immigration officer shall record sufficient information in the sworn statement to establish and record that the alien has indicated such intention, fear, or concern, and to establish the alien's inadmissibility.").

212. Id. $\S 235.3(\mathrm{~b})(2)(\mathrm{i})$ ("[E]xamining immigration officer shall create a record of the facts of the case and statements made by the alien.... Following questioning and recording of the alien's statement regarding identity, alienage, and inadmissibility, the examining immigration officer shall record the alien's response to the questions contained on Form I-867B, and have the alien read (or have read to him or her) the statement, and the alien shall sign and initial each page of the statement and each correction. The examining immigration officer shall advise the alien of the charges against him or her on Form I-860, Notice and Order of Expedited Removal, and the alien shall be given an opportunity to respond to those charges in the sworn statement.").

213. Author and psychologist Malcom Gladwell explored the effect that increased prosecution has on deterring future crimes. See MALCOLM GLADWELl, DAVID AND GOLIATH: UNDERDOGS, MisfiTS, AND THE ART OF BATTLING GIANTS (2013). Gladwell explicates that increased prosecution has a corresponding deterrent effect only up to a certain point, and that point is often the legitimate or perceived legitimate use of government power. Id. at 197-231 (discussing the "principals of legitimacy" in relation to the Troubles in Northern Ireland between the Protestants and the Catholics). Once a government or law begins to prosecute or punish in a way that the individuals perceive as illegitimate, increased prosecution tends to have an opposite deterrent effect and further exacerbates offenses. In other words, the relationship between the prosecution of offenses and deterring future crimes is a U-shaped bell curve, and further prosecution has the opposite effect on deterring future offenses if the power is not used legitimately. Id. at 238-62 (discussing California's experimentation of the strict Three-Strike law). If an individual is removed through coerced consent, that removal is illegitimate and is unlikely to have a positive deterrent effect on preventing future illegal entries, according to Gladwell. In fact, the increased pressure to deport as many individuals as possible through the current administration's "zero-tolerance" policy arguably has the reverse effect on 
Congress needs to consider coerced consent due process violations seriously, and until it does courts should not hesitate to enforce Mirandalike requirements and a Bivens remedy against individual officers in the few cases that do make it to federal court. Unlike many other areas of law where constitutional violations occur, the nature of these violations precludes judicial review unless the foreign national is fortunate enough to return to the United States and afford an attorney. The lack of possible review for coerced consent violations must serve as an important reminder to Congress and courts alike for the necessity to implement meaningful change.

curbing illegal immigration, and the statistics appear to be corroborating Gladwell's theory. See Lori Robertson, Illegal Immigration Statistics, FACTCHECK.ORG (June 28, 2018), https://www.factcheck.org/201 8/06/illegal-immigration-statistics/ [https://perma.cc/6544-MXEN]. 